\title{
Transmission of Avian Influenza Virus by Humpback Whale and Its Stranding along the Atlantic Coast with $\mathrm{CO}_{2}$ Emissions
}

\author{
Tai-Jin Kim
}

Department of Chemical Engineering, University of Suwon, Hwaseong City, South Korea

Correspondence to: Tai-Jin Kim, tjkim@suwon.ac.kr

Keywords: Transmission, Avian Influenza Virus, Humpback Whale, Stranding, $\mathrm{CO}_{2}$ Emissions

Received: November 21, $2018 \quad$ Accepted: December 26, $2018 \quad$ Published: December 29, 2018

Copyright $\odot 2018$ by author and Scientific Research Publishing Inc.

This work is licensed under the Creative Commons Attribution International License (CC BY 4.0).

http://creativecommons.org/licenses/by/4.0/

\section{(c) (i) Open Access}

\section{ABSTRACT}

Humpback whales are migratory, spending summers in cooler, high-latitude waters and mating and calving in tropical and subtropical waters in 14 identified district population segments. It may be possible that the coastal areas are infected with low pathogenic avian influenza (LPAI) during the release of infected humpback whale feces. Therefore, humpback whales can be an effective reservoir of the avian influenza virus (AIV) from the Poles to the Continents to spread AIV to coastal animals. Strong ultraviolet (UV) exposure amidst $\mathrm{CO}_{2}$ emission increase and minimal sunspot number might cause mutations of aquatic virus and humpback whale in the Antarctic and the Arctic. LPAI or highly pathogenic avian influenza (HPAI) is expressed in the Continents under appropriate environmental factors. Since penguins are birds while humpback whales are marine mammals, the humpback whales infected by the mutant virus might cause interspecies transmission to a new host with evolutionary changes. The migration pattern is seasonally similar between migratory bird and humpback whale except: 1) different species of bird versus whale, 2) different landing area of land versus coast, 3 ) similar infection means of bird feces versus humpback whale feces. The contribution of AIV transmission by whales was several times larger than that by migratory birds. Therefore, the routes of humpback whales should be considered to prevent AIV outbreaks in addition to the flyways of migratory birds. Humpback whale stranding ( $y$ ) along the Atlantic Coast of the USA was correlated with $\mathrm{CO}_{2}$ emissions $(x)$ to have $y=$ $0.3515 x+18.595\left(R^{2}=0.4069\right)$ during 1992-2016 while $y=0.0652 x+4.5847,\left(R^{2}=0.6128\right)$ during 2016-2018. AIV outbreak in $2010(y)$ along the Atlantic Coast was also correlated with humpback whale stranding $(2016-2018)(x)$ as $y=0.1387 x+6.8184\left(R^{2}=0.3966\right)$. Since AIV outbreak was linearly $\left(R^{2}=0.9967\right)$ correlated with the minimum sunspot number, it 
was postulated that the unusual mortality events of humpback whale stranding might be caused by an infected mutant virus in the Arctic. Consequently, the humpback whales were stranded along major $\mathrm{CO}_{2}$ producing Atlantic Coast States toward the winter habitat of the West Indies during the $\mathrm{CO}_{2}$ emissions and the minimal sunspot number with strong UV radiation. The stranded dead whales should be burned as soon as possible to prevent further deadly viral interspecies transmission of AIV by the coastal animals. Since $\mathrm{CO}_{2}$ emissions were increased in 2017 and the sunspot number was minimal at the end of 2018, serious numbers of whales are expected to be stranded at the Gulf of Maine, States of North Carolina, New York, and Virginia from November 2018 till April 2019. To save humpback whales from the unusual mortality event along the Atlantic Coast, the reduction of $\mathrm{CO}_{2}$ emissions is suggested by replacement of fossil fuels combustion plants with nuclear power plants along the Atlantic Coast of the USA.

\section{INTRODUCTION}

Coasts are a unique part of the oceans that provide a habitat for many animal species. Birds and bats are numerous on the coast, because there is a reliable source of food there. Seal, sea lion, crab, fish, penguin and humpback whale are animals of the coasts [1]. Aquatic birds are naturally the principal reservoirs for influenza A viruses, including horses, cats, dogs, marine animals, domestic poultry, pigs, bats, and humans. The processes involved in influenza virus evolution are acquisition of mutations, reassortment and less frequently non-homologous recombination [2]. Various highly pathogenic avian influenza virus (HPAIV) outbreaks in 2016 were observed in different countries in the world [3], presumably due to different environments (route of flying birds, kind of migratory birds, sources of North and South Poles, temperature, humidity, $\mathrm{pH}$, kinds of prey (rice, wheat, corn, bullfrog, mudfish, catfish, lungfish), domestic wild birds, wetlands, and intensity of ultraviolet (UV) radiation [4]. 971 seals showed a prevalence of antibodies to the influenza B virus of a human pathogen. This animal reservoir, harboring influenza B viruses that have circulated in the past, may pose a direct threat to humans [5]. Yoon [2] reviewed the cross-species transmission of influenza A viruses to show that wild aquatic birds transmitted avian influenza virus (AIV) to marine mammals, such as harbor seals (H3N3, H4N6, H7N7, H3N8), elephant seal (H1N1), and pilot whale (H13N2, H13N9). There are various whales that can be listed from heaviest to lightest as follows: Blue, fin, right, sperm, bowhead, humpback, orca, minke, beluga and narwhal whales. No one has yet proposed the seaway transmission of AIV by humpback whales although they follow annually the similar seasonal migration pattern of migratory birds from the Poles to the Continents. The present study investigated the similarity of AIV transmission in the seasonal migration between migratory birds and humpback whales from low-latitude grounds (Poles) to high-latitude grounds (Continents) so that the possibility of AIV transmission was additionally proposed to be through the seaway transmission by humpback whales.

Humpback whales have been dying in extraordinary numbers along the Atlantic Coast as an unusual mortality event. In the present study, the causes of humpback whale stranding along the Atlantic Coast were initiatively related with both of $\mathrm{CO}_{2}$ emissions and the minimal sunspot number.

\section{FLYWAYS OF MIGRATORY BIRDS}

It is well known that AIV is transmitted by migratory birds, as shown in Figure 1.

\section{SEAWAYS OF MIGRATORY HUMPBACK WHALES}

The humpback whale (Megaptera novaeangliae) is a species of baleen whale (shown in Figure 2). One of the larger rorqual species, adults range in length from 12 - 16 meters and weigh approximately 25 - 40 tons 


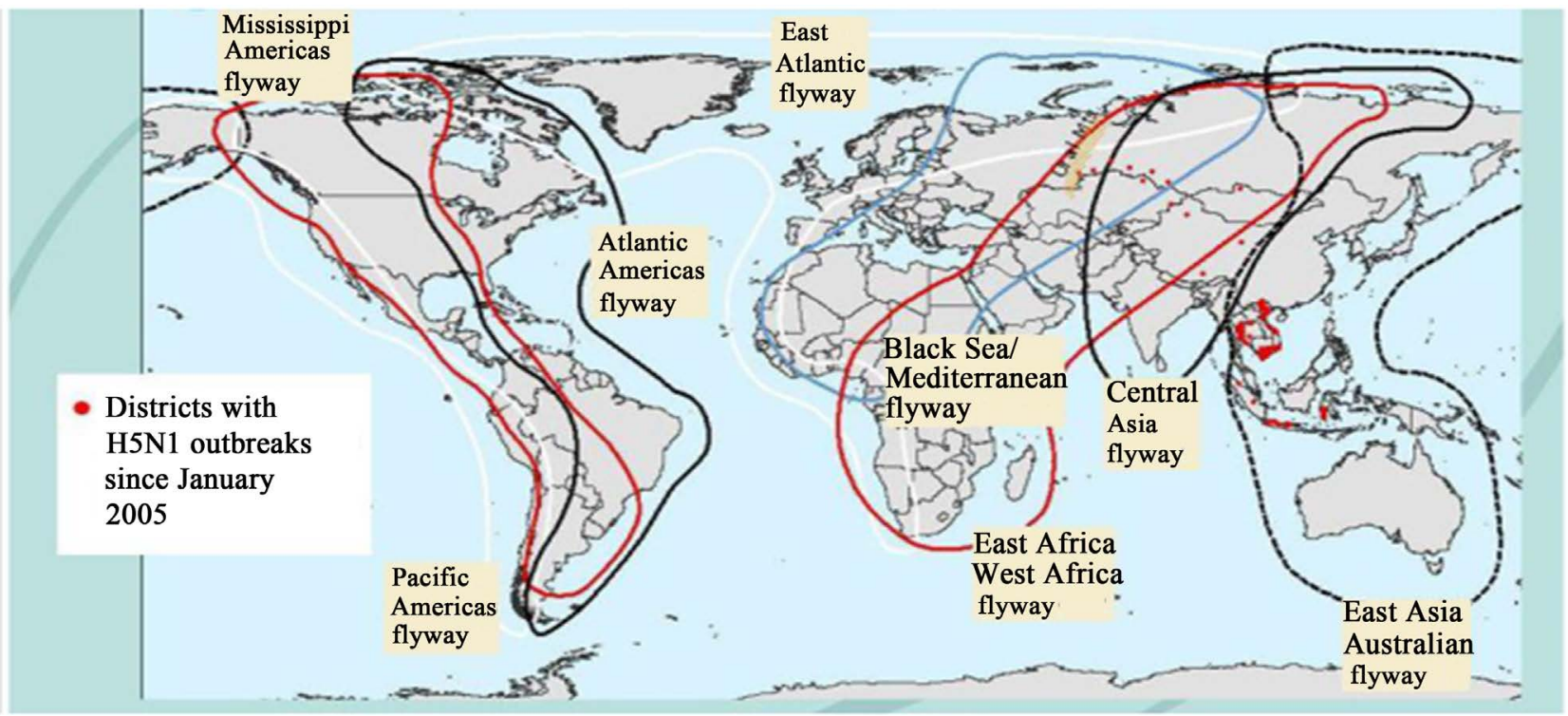

Figure 1. H5N1 outbreaks since 2005 and major flyways of migratory birds [6].

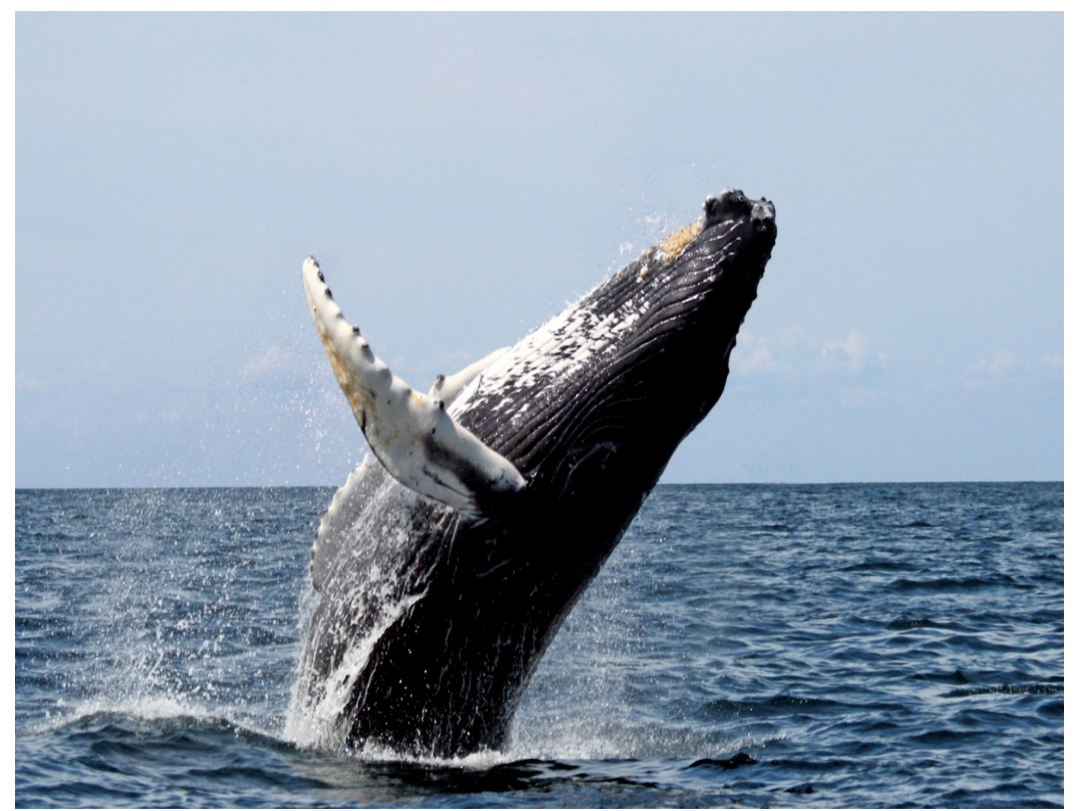

Figure 2. Humpbacks frequently breach, throwing two-thirds or more of the bodies out of the water and splashing down on their backs [7].

with life expectancy of 45 - 50 years. The humpback is an energetic hunter, taking krill and small schooling fish. Krill and copepods have been recorded as prey species in Australian and Antarctic waters. Humpbacks inhabit all major oceans, in a wide band running from the Antarctic ice edge to $77^{\circ} \mathrm{N}$ latitude, though not in the eastern Mediterranean or the Baltic Sea (Figure 3). Humpback whales live at the surface of the ocean, both in the open ocean and shallow coastal waters. When not migrating, they prefer shallow waters [7]. They are migratory, spending summers in cooler, high-latitude waters and mating and calving in tropical and subtropical waters. Global migration routes of humpback whales are shown in Figure 4. An exception to this rule is a population in the Arabian Sea, which remains in these tropical waters year-round. 


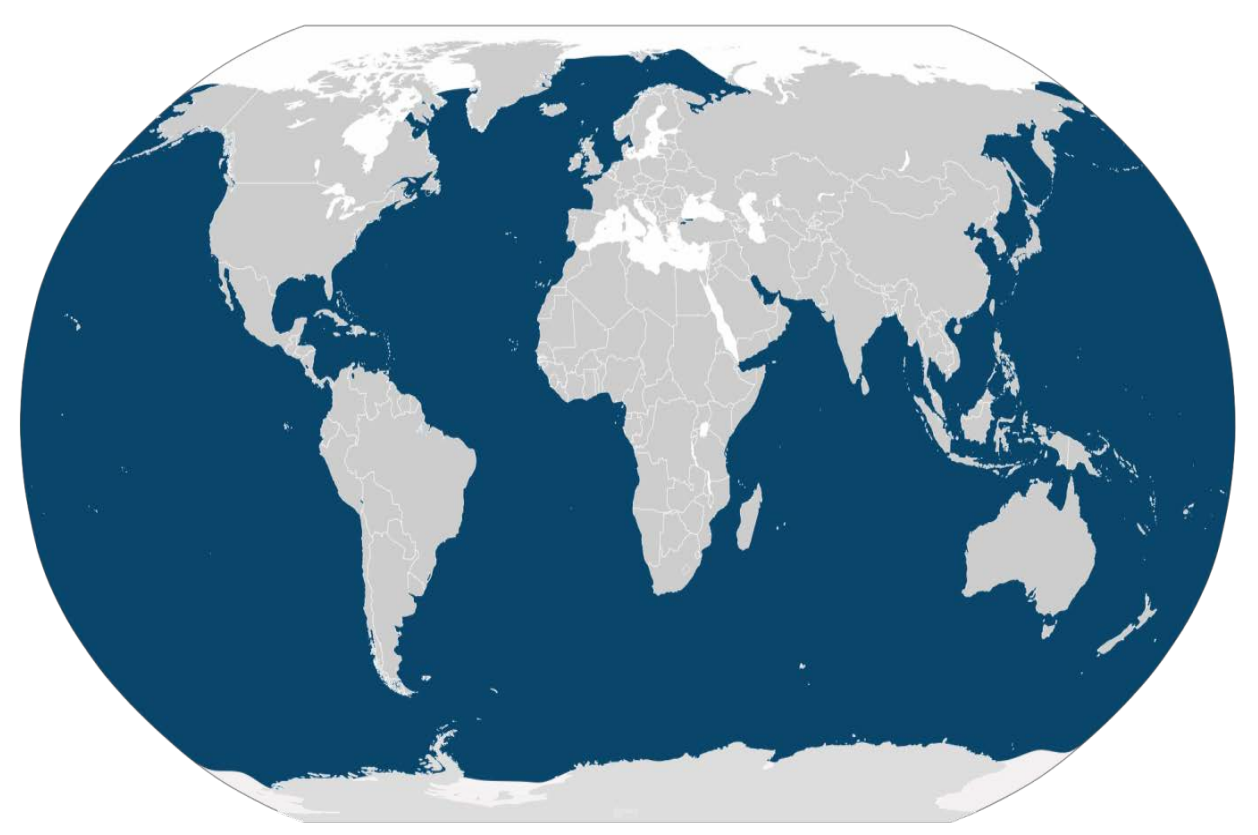

Figure 3. Range of humpback whale (Megaptera novaeangliae) [7].

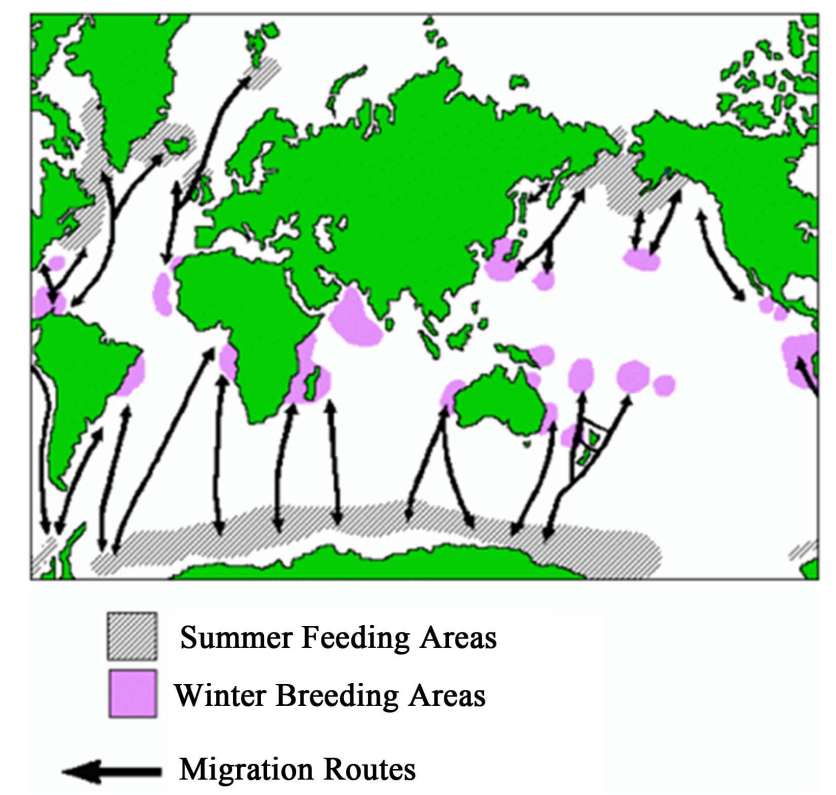

Figure 4. Migratory routes of humpback whales from summer poles to winter continents [8].

Annual migrations of up to 25,000 kilometers are typical, making it the most traveled species of all mammals. Worldwide population is at least 80,000 humpback whales, with 18,000 - 20,000 in the North Pacific, about 12,000 in the North Atlantic, and over 50,000 in Southern Hemisphere, down from a prewhaling population of 125,000 [7], as shown in Table 1 .

Humpback whales are generally curious about objects in their environments. Some individuals, referred to as "friendly", approach whale-watching boats closely, often staying under or near the boat for many minutes. Because humpbacks are often easily approachable, curious, easily identifiable as individuals, and display many behaviors, they have become the mainstay of whale-watching tourism in many locations around the world [7], as shown in Table 1 and Figure 2. 
Table 1. Seasonal location of humpback whale [7].

\begin{tabular}{|c|c|c|c|}
\hline Season & North Atlantic & North Pacific & Southern Hemisphere \\
\hline Summer & $\begin{array}{l}\text { New England, Nova Scotia and } \\
\text { Newfoundland, the northern St. } \\
\text { Lawrence River, the Snaefellsnes } \\
\text { Peninsula in the west of Iceland }\end{array}$ & $\begin{array}{l}\text { California, Alaska, } \\
\text { Oregon, Washington, } \\
\text { British Columbia }\end{array}$ & $\begin{array}{l}\text { Antarctica, Bahía Solano } \\
\text { and Nuquí in Colombia }\end{array}$ \\
\hline Winter & $\begin{array}{l}\text { Samanaá Province of the } \\
\text { Dominican Republic, the Bay of } \\
\text { Biscay France, Mona Passage } \\
\text { off the coast of Puerto Rico }\end{array}$ & $\begin{array}{l}\text { Hawaii, Baja, the } \\
\text { Bahía de Banderas } \\
\text { off Puerto Vallarta }\end{array}$ & $\begin{array}{l}\text { Sydney, Byron Bay north of } \\
\text { Sydney, Hervey Bay north of } \\
\text { Brisbane, North and East Cape } \\
\text { Town, New Zealand, the } \\
\text { Tongan islands, Victor } \\
\text { Harbor and outlying beaches }\end{array}$ \\
\hline
\end{tabular}

The distribution of 14 identified humpback whale district population segments [9] are well described in Figure 5.

It is thought that humpback whales in the Arabian Sea in Figure 5 (14) exhibit self feeding and breeding without movement to high-latitude. Arabian Sea is surrounded by volcanoes (Saudi Arabia; 24, Yemen 13, Iran; 7, Iraq; 1, India; 4, Pakistan; 7) for sufficient nutrients, and deserts (Arabian, Syrian, Iranian) (Indus, Mahi, Tapti, and Shatt al Arab) for iron and minerals to grow algae and fish.

Migration patterns for humpback whale are shown in Figure 4 and Figure 5. Humpback whales can be found in the Bering Sea, Aleutian Islands, Prince William Sound, Glacier Bay and throughout the Inside Passage of South East Alaska in the summer. In the winter they move south to the Banderas Bay in Mexico, Baja California and the Hawaiian islands. They spend the spring, summer and fall months in the cooler waters around Alaska and head for warmer waters in the winter months. Their diet consists of krill and many different kinds of fish including chovies, sardines, herring and capelin. They eat one to one and a half tons of food a day. During winter months they don't feed but live off fat reserves in their blubber. The humpback whale's main predator is the killer whale. Commercial whalers were allowed to hunt humpbacks into the 20th century. Today as whales live so close to the coastlines they are often hurt by pollution, collision with boats and getting tangled in fishing nets. Humpback whales live throughout the world's oceans with the exception of the extreme northern Arctic waters. The humpback whales that summer in the North Pacific are from three separate groups that spend their winter month in Mexico, in Hawaii, or the Western Pacific near the Mariana, Bonin, and Ryukyu islands. The humpback whales seen in the summers in Alaska are primarily from Hawaii [10]. July is usually the mating season for Southern Hemisphere humpback whales, with births occurring in June of the subsequent year. A calf is generally strong enough to migrate with its mother at three months old [11], i.e. around September of the year it was born. Between October and mid-May each year, migratory humpback whales visiting warm tropical waters for calving and breeding are the stars of the local whale watch tours [12]. Humpback whales have been observed not only in three HNLC (High Nutrients Low Chlorophyll) regions of the Subarctic Pacific (Alaska), the Equatorial Pacific (Galapagos) and the Southern Ocean (Bransfield Strait, Gerlache Strait, South Georgia, Crozet, Kerguelen) but also in four LNLC (Low Nutrients Low Chlorophyll) regions of Iceland (Snaefellsnes Peninsula), Japan (Zamami), Guam, and Hawaii (Maui) along with five coastal upwelling HNHC (High Nutrients Low Chlorophyll) regions (Benguela, Canary, California-Monterey Bay, Humboldt-Galapagos, Somali) and eight hot fishery oceans of LNHC (Low Nutrients Low Chlorophyll) regions (Pacific coast of Mexico, Northeast Pacific, Northwest Pacific, Northeastern Canada, Peruvian coast, New Zealand, Southern Africa, The Antarctic). However, five locations in the Southern Ocean (Bransfield Strait, Gerlache Strait, South Georgia, Crozet, Kerguelen) were more suitable ones due to the 


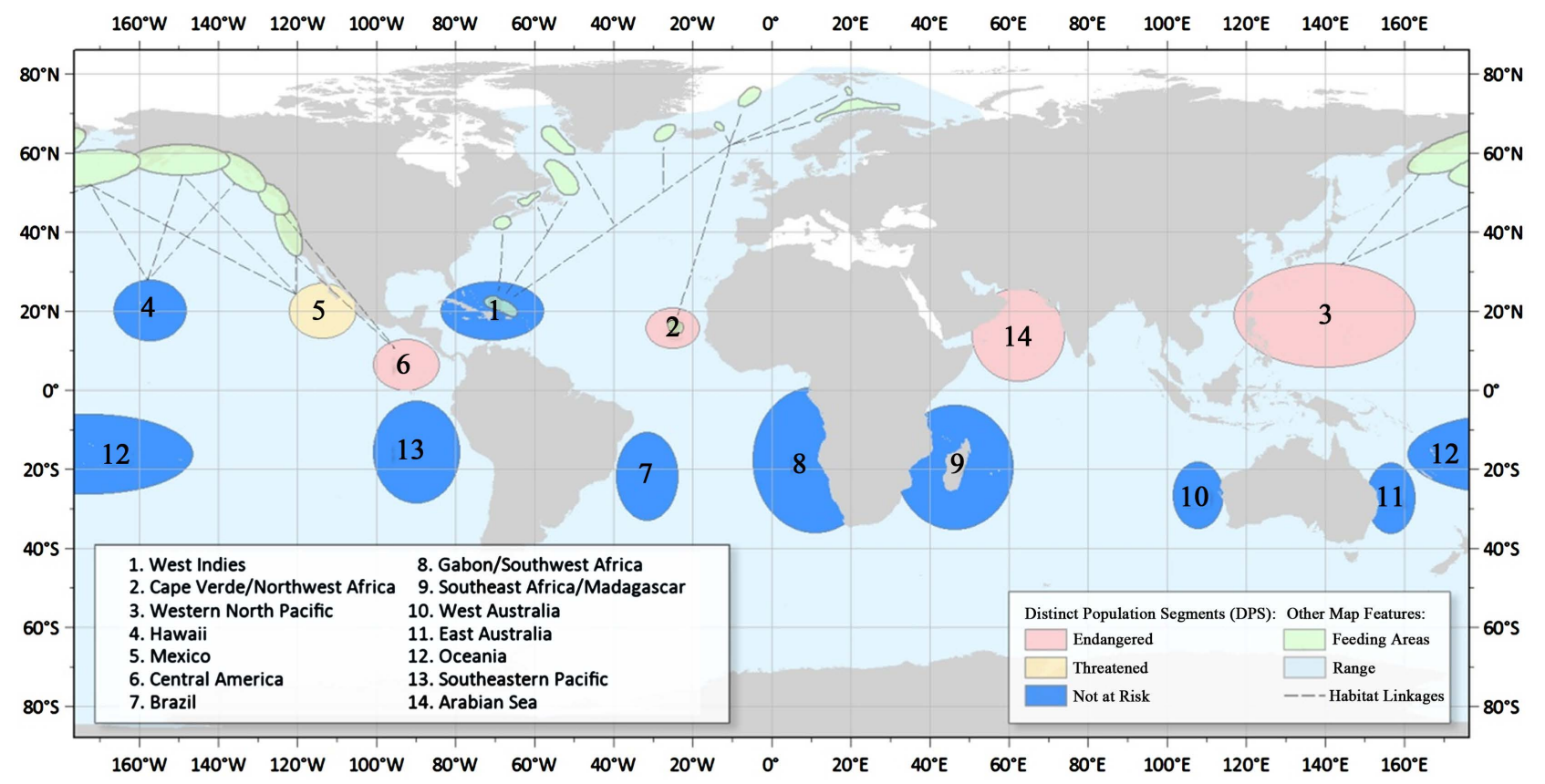

Figure 5. The distribution of 14 identified humpback whale district population segments [9].

availability of iron from upwelling and hydrothermal vents [13] with enriched nutrients and high mass flow rate of ACC for a wide natural bloom area during the warm austral summer [14]. High densities of humpback whales (153 observed in the Gerlache Strait) coincided with blooms of phytoplankton in the spring [15]. Additional locations with estimated numbers of humpback whale in parentheses, such as North Atlantic (11,570), Mexico (7000), SW Atlantic (6251), SW Indian Ocean (8497), SE Indian Ocean (10,032), NE Australia (7090) were estimates of abundance and trends for humpback whales in their breeding grounds [16].

\section{PILOT WHALE}

Pilot whales are cetaceans belonging to the genus Globicephala. The two extant species are the long-finned pilot whale ( $G$. melas) and the short-finned pilot whale ( $G$. macrorhynchus). Between the two species, they range nearly worldwide, with long-finned pilot whales living in colder waters and short-finned pilot whales living in tropical and subtropical waters, as shown in Figure 6. The long-finned pilot whale prefers slightly cooler waters than the short-finned, and is divided into two populations. The smaller group is found in a circumpolar band in the Southern Ocean from about 20 to $65^{\circ} \mathrm{S}$. It may be sighted off the coasts of Chile, Argentina, South Africa, Australia, and New Zealand. It is estimated that more than 200,000 individuals were in this population in 2006. The second, much larger, population inhabits the North Atlantic Ocean, in a band from South Carolina in the United States across to the Azores and Morocco at its southern edge and from Newfoundland to Greenland, Iceland, and northern Norway at its northern limit. This population was estimated at 778,000 individuals in 1989. It is also present in the western half of the Mediterranean Sea. The short-finned pilot whale is less populous. It is found in temperate and tropical waters of the Indian, Atlantic and Pacific Oceans. Its population overlaps slightly with the long-finned pilot whale in the temperate waters of the North Atlantic and Southern Oceans. About 150,000 individuals are found in the eastern tropical Pacific Ocean. More than 30,000 animals are estimated to live in the western Pacific, off the coast of Japan. Pilot whales are generally nomadic, but some populations stay year-round in places such as Hawaii and parts of California. They prefer the waters of the shelf break and slope [17]. Humpback whales are in contact with pilot whales in oceans so that humpback whales infected by mutant virus in the Poles may transmit their mutant virus to pilot whales. 


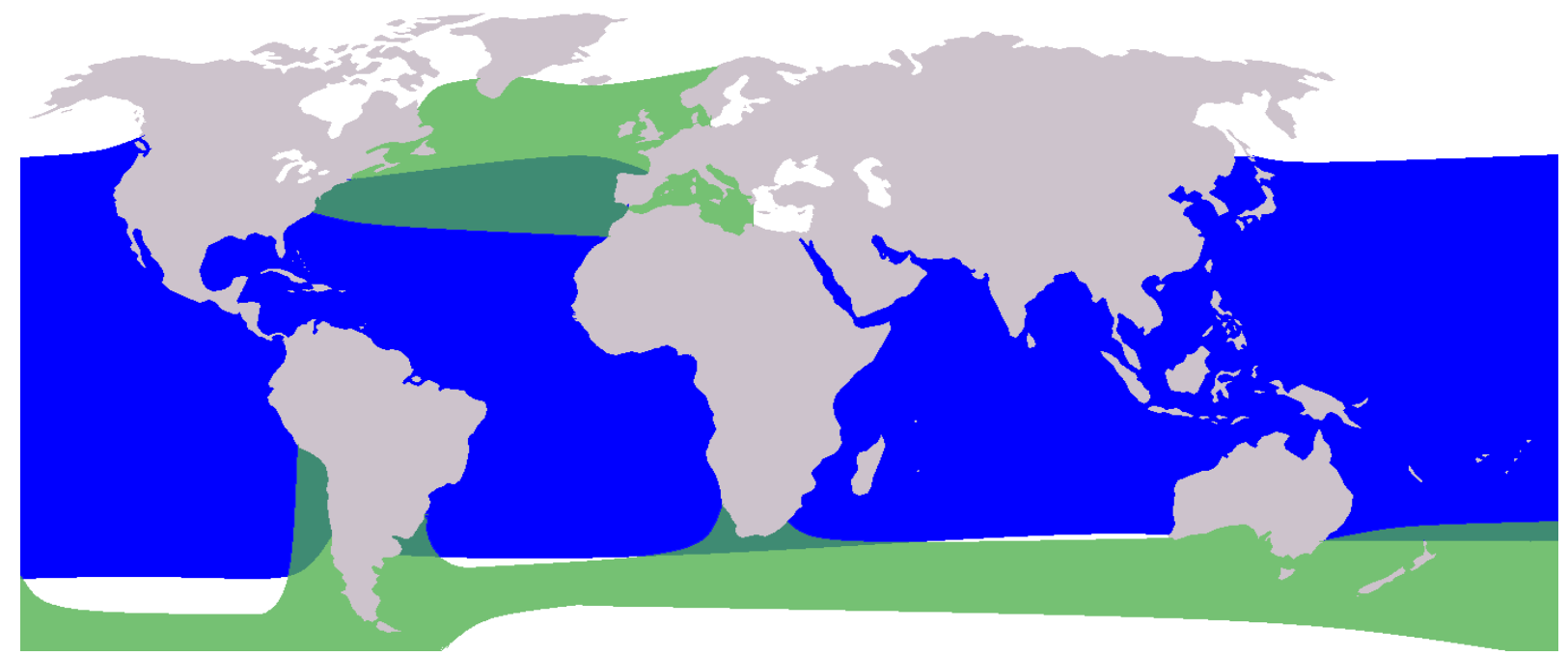

Figure 6. Global range map of pilot whale (green: long-finned; blue: short-finned) [17].

\section{TRANSMISSION OF AIV BY HUMPBACK WHALE}

Table 2 revealed that the outbreaks of HPAI H5N1 associated with humpback whale habitat, were absent in Australia where there were strong UV-B radiations induced by the deterioration of ozone hole in Antarctica. However, there have been five known outbreaks of avian influenza in Australia in 1976, 1985, 1992 (H7N3), 1994 and 1997 (H7N4) [18], which were in agreement with the times of the minimal sunspot numbers during 1976, 1986, and 1995 [19]. It can be summarized that Australia may observe the outbreaks of AIV during the minimal sunspot areas with strong UV-B exposure. Humpback whales feed on krill and small fish in Antarctica and Arctica while migrating to tropical or subtropical waters during the winter breeding in Northern and Southern Hemispheres. It may be possible to infect the coastal areas with LPAIV during the release of humpback whale infected feces of 1.5 ton per day from the Polar waters into tropical or subtropical waters. Although humpback whales stay at the Poles under strong UV radiations, they usually reside in coastal areas $50 \mathrm{~m}$ below the sea level. Therefore, the hazard of UV radiation affecting humpback whales is negligible since UV radiation reaches only $3 \mathrm{~m}$ below the sea surface. However, the seawater has low salinity caused by ice melting due to strong UV radiation. This may vitalize the mutant virus to be fed by bacteria, algae, krill, fish while humpback whales may sustain as a reservoir of mutant virus of LPAIV to be transmitted from the Poles to the warm seashores in the Continents. Figure 4 shows the migratory routes for the summer feeding areas and winter breeding areas of humpback whale, which indicates the similar behavior of migrating birds (Figure 1) between Poles and Continents.

The routes of humpback whale habitats, flyways of migratory birds, aeolian desert dusts, rice and wheat production, and UV-B radiation were nearly superimposed with locations $\mathrm{H} 5 \mathrm{~N} 1$ outbreaks in Table 2. However, there were exceptions with habitat number in Figure 5 such as Hawaii (4), Brazil (7), Madagascar (9), West Australia (11), and Southeastern Pacific (13), where the ozone layer deterioration from Poles are spread around resulting in the strong UV radiation and inhibiting the AIV outbreaks (Figure 9(b)).

The penguin is a bird (avian) while the humpback whale is a mammalian animal. Therefore, the humpback whales infected by the mutant virus cause interspecies transmission as the virus adapts to a new host with evolutionary changes. Coastal animals such as birds, bats, dolphins, and whales should be careful not to transmit evolutionary AIV, especially during the periods when $\mathrm{CO}_{2}$ emissions increase and the minimal sunspot number period [4]. Figure 7 shows the schematic diagram of migratory birds and humpback whales infected by the aquatic virus mutant in the Poles which transmits AIV to migratory birds and evolutionary AIV to humpback whales in the Continents during $\mathrm{CO}_{2}$ emission increase and minimal sunspot number. 
Table 2. Outbreak of AIV associated with humpback whale habitat, flyway of migratory bird, desert, rice production, UV-B radiation.

\begin{tabular}{|c|c|c|c|c|c|c|}
\hline ID & $\begin{array}{c}\text { Humpback } \\
\text { Whale Habitat } \\
\text { (Figure 5) }\end{array}$ & $\begin{array}{l}\text { Flyways of } \\
\text { Migratory Birds } \\
\text { (Figure 1) }\end{array}$ & Deserts & $\begin{array}{c}\text { H5N1 } \\
\text { Outbreak } \\
\text { (Figure 9(b)) }\end{array}$ & $\begin{array}{l}\text { Rice/Wheat } \\
\text { Production }\end{array}$ & $\begin{array}{c}\text { UV-B } \\
\text { Radiation }\end{array}$ \\
\hline 1 & West Indies & Atlantic Americas & Sahara & $\mathrm{O}$ & $\mathrm{O}$ & $\Delta$ \\
\hline 2 & Northwest Africa & $\begin{array}{c}\text { Black } \\
\text { Sea/Mediterranean }\end{array}$ & Sahara & $\mathrm{O}$ & $\mathrm{O}$ & $\mathrm{O}$ \\
\hline 3 & $\begin{array}{c}\text { Western } \\
\text { North Pacific }\end{array}$ & East Asia/Australian & Asian & $\mathrm{O}$ & $\mathrm{O}$ & $\Delta$ \\
\hline 4 & Hawaii & East Asia/Australian & Asian & $\mathrm{X}$ & $\mathrm{O}$ & $\Delta$ \\
\hline 5 & Mexico & Mississippi Americas & Sonoran & $\mathrm{O}$ & $\mathrm{O}$ & $\Delta$ \\
\hline 6 & Central America & Mississippi Americas & Sonoran & $\mathrm{O}$ & $\mathrm{O}$ & $\Delta$ \\
\hline 7 & Brazil & Atlantic Americas & Sahara/Patagonia & $\Delta$ & $\mathrm{O}$ & $\mathrm{O}$ \\
\hline 8 & $\begin{array}{c}\text { Gabon/Southwest } \\
\text { Africa }\end{array}$ & East Atlantic & Namib & $\mathrm{O}$ & $\mathrm{O}$ & $\Delta$ \\
\hline 9 & $\begin{array}{c}\text { Southeast } \\
\text { Africa/Madagascar }\end{array}$ & $\begin{array}{l}\text { East Africa } \\
\text { West Asia }\end{array}$ & Kalahari/Karoo & $\Delta$ & $\mathrm{O}$ & $\mathrm{O}$ \\
\hline 10 & West Australia & East Asia/Australian & $\begin{array}{c}\text { Great } \\
\text { Sandy/Great } \\
\text { Victoria }\end{array}$ & $\mathrm{X}$ & $\mathrm{O}$ & $\mathrm{O}$ \\
\hline 11 & East Australia & East Asia/Australian & Simpson & $\mathrm{X}$ & $\mathrm{O}$ & $\mathrm{O}$ \\
\hline 12 & Oceania & Central Pacific & $\mathrm{X}$ & $\Delta$ & $\mathrm{O}$ & $\Delta$ \\
\hline 13 & $\begin{array}{c}\text { Southeastern } \\
\text { Pacific }\end{array}$ & Pacific Americas & Sechura & $\mathrm{X}$ & $\mathrm{O}$ & $\Delta$ \\
\hline 14 & Arabian Sea & Central Asian & $\begin{array}{l}\text { Thar/Rub } \\
\text { Al-Khali }\end{array}$ & $\mathrm{O}$ & $\mathrm{O}$ & $\mathrm{O}$ \\
\hline
\end{tabular}

${ }^{*}$ Note: O: Strong, $\Delta$ : Mild, X: Negligible, as defined in Kim [4].

Figure 7 implies that penguins and humpback whales share together the feed of infected krill to generate LPAIV in penguins and induce the evolutionary AIV in humpback whales. Migratory birds transmit LPAIV from penguins to propagate LPAIV/HPAIV in the Continents causing serious harm to poultry and humans. Humpback whales migrate to Continents for interspecies transmission at coastal animals such as whale, seal, dolphin, bat, and bird, whose evolutionary AIV may be transmitted to poultry and humans.

AIV has a reservoir of bird penguins, whose mutant virus is transmitted by migratory birds to Continents. Humpback whale is a reservoir of mammalian animal, whose mutant virus of evolutionary AIV is transmitted by humpback whale itself to Continents. The migration pattern is seasonally similar between migratory bird and humpback whale except: 1) different species of bird versus whale, 2) different landing area of land versus coast, 3 ) similar infection means of bird feces versus humpback whale feces. 


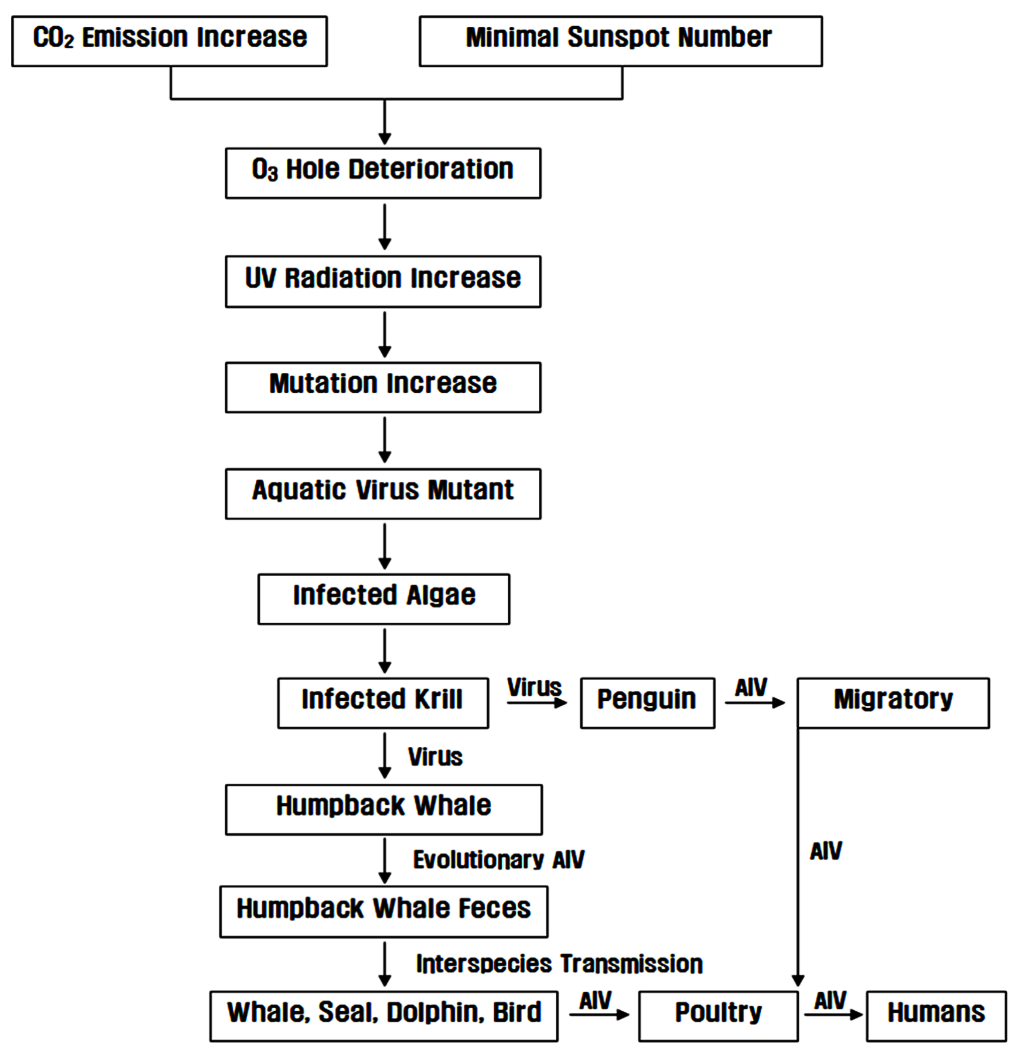

Figure 7. Transmission of AIV by both of migratory birds and migratory humpback whales infected by aquatic virus mutant in the Poles to poultry and humans in the Continents during $\mathrm{CO}_{2}$ emission increase and minimal sunspot number.

Aeolian dust in Antarctic and Arctic deserts move to breeding migratory birds at such regions where small ozone holes deteriorated by global warming allow strong UV-B exposure and mutation to virus, bacteria, phytoplankton, zooplankton, krill, small fish, squid, penguin, migratory birds, and humpback whales. Such a mutant virus infected or held by migratory birds and humpback whales in the Poles moves to the Continents for food and breeding, where LPAI are expressed as HPAI under appropriate environmental factors such as UV-B radiation, salinity, temperature, relative humidity, aeolian dust, precipitation, and wind direction. Mutant viruses persisting in host cells of aquatic bacteria are food web prey of algae, krill, small fish, squid, and finally penguin and humpback whales. Penguins, as birds, can have a weak immunity due to starvation through the shortage of algae beneath the ice in warm winter, especially during the period of the $\mathrm{CO}_{2}$ emission increase and the minimal sunspot number with strong UV radiation and warm air surface temperature. Such a weak penguin infected by mutant virus may generate and hold LPAI AIV to transmit to the Continents via migratory birds. Humpback whales feed on krill and small fish, infected by the mutant aquatic virus. Since a penguin is a bird while a humpback whale is a coastal animal or marine mammal, AIV transmitted by migratory birds were H1-H10 while evolutionary AIV transmitted from humpback whales to presumably pin whales were H13 [2]. AIV, initiated from aquatic viruses with mutation by strong $\mathrm{UV}$ radiation during the $\mathrm{CO}_{2}$ emissions increase and the minimal sunspot number, is held in penguins and humpback whales until penguins transmit their AIV via migratory birds through flyways in the air (Figure 1) and humpback whales transmit evolutionary AIV via oceanic migration routes through feeding and breeding areas in the seawater (Figure 4). It is interesting to note that marine mammals such as harbor seals, elephant seals, and pilot whales were infected by evolutionary AIV near the habitats of coastal line [2] while the humpback whale prefers to stay at the coast less than $50 \mathrm{~m}$ underwater. Since penguins are birds while humpback whales are marine mammals, their strains of AIV 
cannot be the same. Pilot whales showed unique H13N2 and H13N9 while wild aquatic birds are H1 - H10 subtypes and bats are H17 - H18 ones [2]. Therefore, marine mammals with AIV such as harbor seals (H3N3, H3N8, H4N5, H4N6, H7N7), elephant seals (H1N1), and pilot whales (H3, H4, H7, H13) could be directly infected by humpback whale feces and indirectly infected by wild aquatic birds. The direction of AIV transmission for the marine mammals could be from the humpback whales to presumably the marine mammals, rather than the other way. There are aquatic food web cycles starting from virus, bacteria, phytoplankton, zooplankton, krill, small fish, squid, penguin, and humpback whale. Therefore, if there is strong UV radiation during the $\mathrm{CO}_{2}$ emissions increase and the minimal sunspot number period, the aquatic virus is mutated. Consequently, penguins and humpback whales are easily infected by mutant AIV through food web cycles. It can be postulated that penguins are the main reservoir of AIV whose mutant virus, induced by strong UV-B radiation during the 11-year periodic minimal sunspot number (Figure 8), are transmitted from penguins in Antarctica and guillemot in Arctica to Continents by mainly migratory birds and partly humpback whales with evolutionarily mutated AIV.

Humpback whale habitats (Figure 9(a)) and migratory flyways (Figure 1) of wild bird populations are similar to those of AIV persistence (Figure 9(b)). On the other hand, areas with strong UV-B radiation for skin cancers [4] are excluded due to the retardation of AIV viability in Greenland, Scandinavian countries, Australia, New Zealand, South America, southern Africa.

Humpback whales feed on krill and small fish in Antarctica and Arctica while migrating to tropical or subtropical waters during the winter breeding in the Northern and Southern Hemispheres. It may be possible that the coastal areas are infected with evolutionary AIV by humpback whales during the release of infected feces of 1.5 ton per day into tropical or subtropical waters. Therefore, humpback whales may be an effective reservoir of evolutionary AIV from the Poles to the Continents to spread AIV to marine mammals and coastal birds. The migratory routes for the summer feeding areas and winter breeding areas of humpback whale (Figure 4), indicate the similar behavior of migratory birds between Poles and Continents (Figure 1).

Figure 9(a) shows that migratory flyways of wild bird are overlapped with the routes of migratory humpback whales. However, there were no AIV outbreaks in Hawaii (4), South America (7, 13), South Africa (9), Oceania (12) and Australia $(10,11)$ with the corresponding number of humpback whale habitat in Figure 5, which could be caused by Asian ozone pollution in Hawaii [21] and ozone layer deteriorations of Antarctica in other regions, respectively. The thin ozone layer induces strong UV radiation so that the outbreak of AIV is suppressed in such a region, as proposed by Kim [4]. Comparison of Figure 9(a) with Figure 9(b) suggests that AIV may be transmitted not only by migratory birds but also by humpback whales. The humpback whale weighs 30 tons weight and has a global population of 80,000 , which is equivalent to 2.4 billion $\mathrm{kg}$. The minke whale weighs 10 tons and has a population of 0.2 million, totally 2 billion $\mathrm{kg}$. The pilot whale, weighing 2 tons, has an approximate population of 1 million with a total of 2 billion $\mathrm{kg}$. The sum of humpback, pilot, and minke whales in the Poles weigh 6.4 billion $\mathrm{kg}$. The body weight of migratory birds was males averaged $16.3 \mathrm{~g}$ and females $17.6 \mathrm{~g}$ for migratory blackcaps [22]. If assuming one kilogram per migratory bird for billions of migratory birds in the world, the contribution of AIV

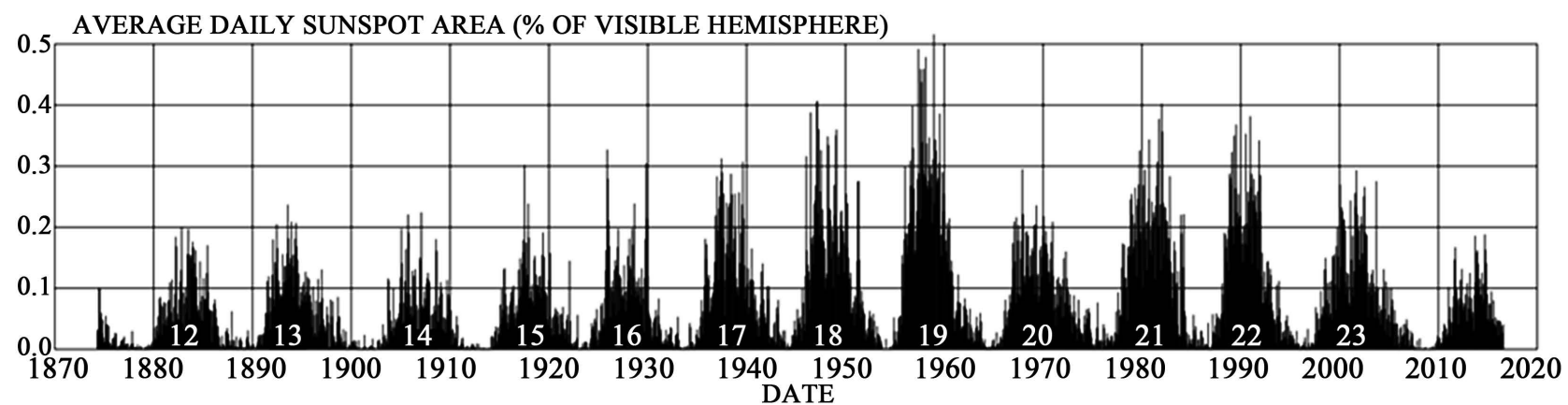

Figure 8. Sunspot number as a function of latitude and time during 1875 to 2016 [20]. 


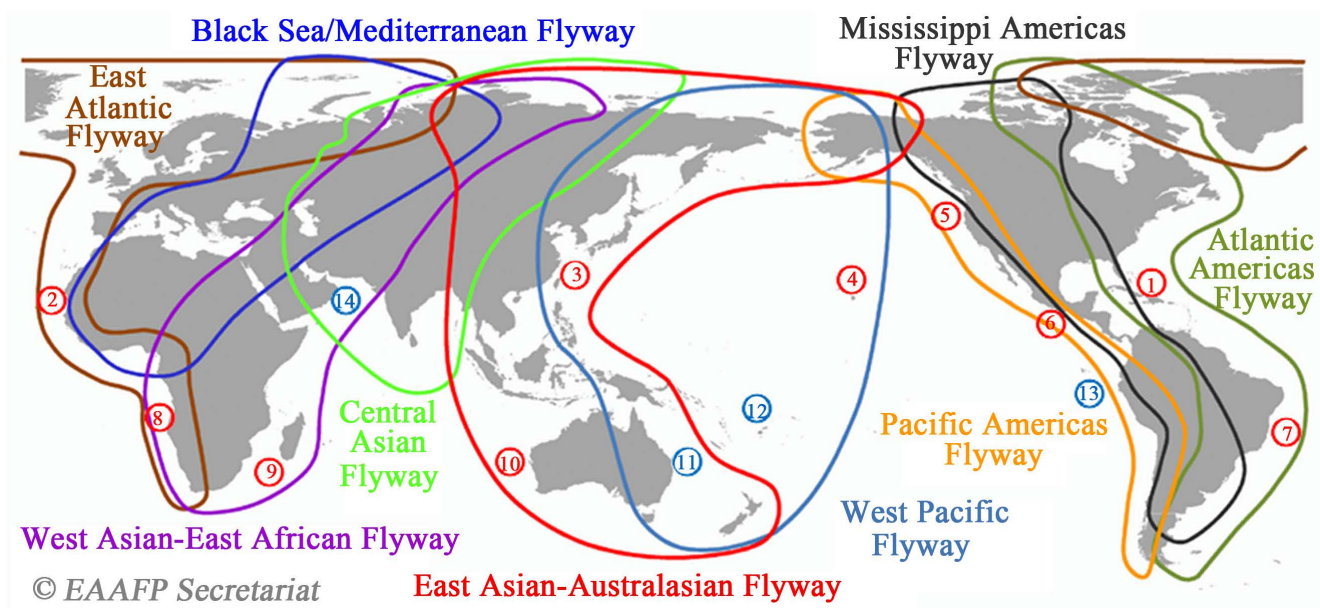

(a)

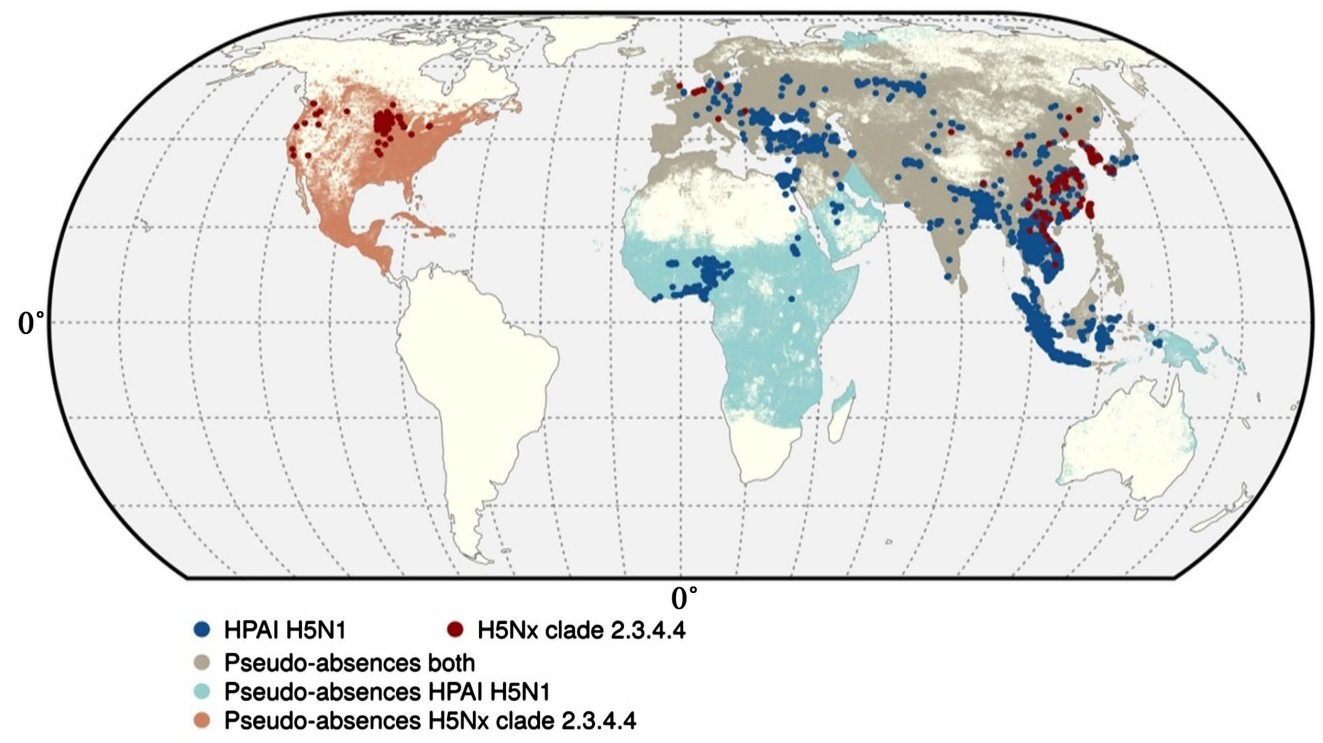

(b)

Figure 9. (a) Migratory flyways of wild bird populations [23] with corresponding numbers of humpback whales habitats in Figure 5 [9], which indicates the similar routes between migratory birds and humpback whales; (b) Global mapping of HPAI H5N1 and H5Nx Clade 2. 3. 4. 4. viruses with spatial cross-validation. eLife, 5, e19571 [24].

transmission by whales are several times larger than that of migratory birds, accounting for the amount of infected feces proportional to the body weight. Therefore, the routes of humpback whale or whales including dolphins and seals should be considered when attempting to prevent of AIV outbreak in addition to the flyways of migratory birds.

Transmissions of evolutionary AIV from the aquatic virus mutant through infected migratory humpback whales to coastal animals, poultry, and humans, were pictorially described in Figure 10.

Figure 11 describes sequential flow diagram of evolutionary AIV outbreak transmitted by migratory humpback whales. The importance of the $\mathrm{CO}_{2}$ emissions increase and the minimal sunspot number dictate the spread of the mutant virus amidst UV radiation for infected krill and humpback whales inducing evolutionary AIV via coastal animals under environmental parameters in the Continents for LPAI/HPAI in poultry and humans. 


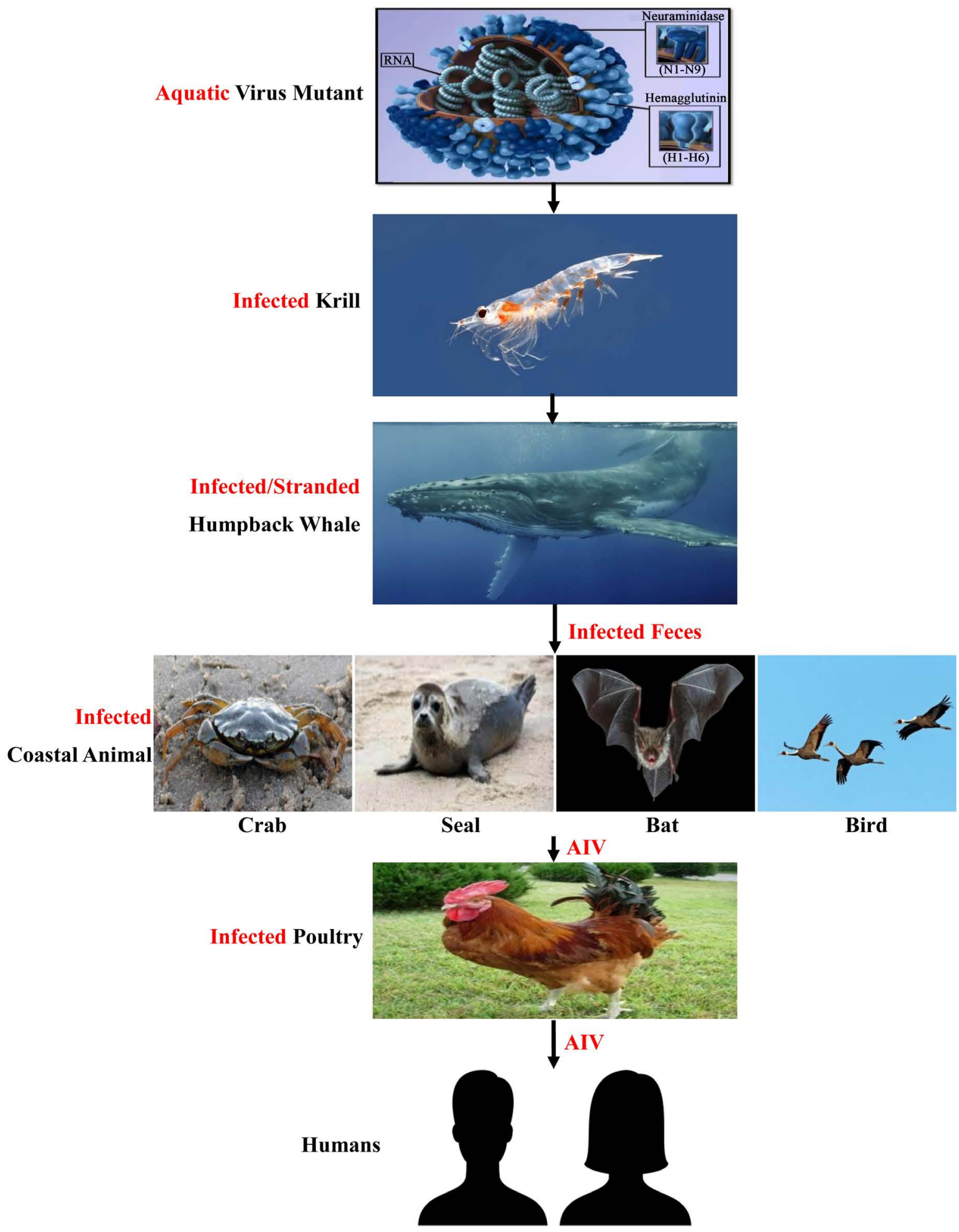

Figure 10. Pictorial presentation for transmissions of AIV from the aquatic virus mutant through infected migratory humpback whales to coastal animals (crab, seal, bat, bird, whale), wild bird, poultry, and humans. Since humpback whales feed on the krill infected by the mutant aquatic virus and small fish, infected humpback whales might be the reservoir of the AIV in the form of infected feces from the Poles to Continents through their regular migratory behaviors. 


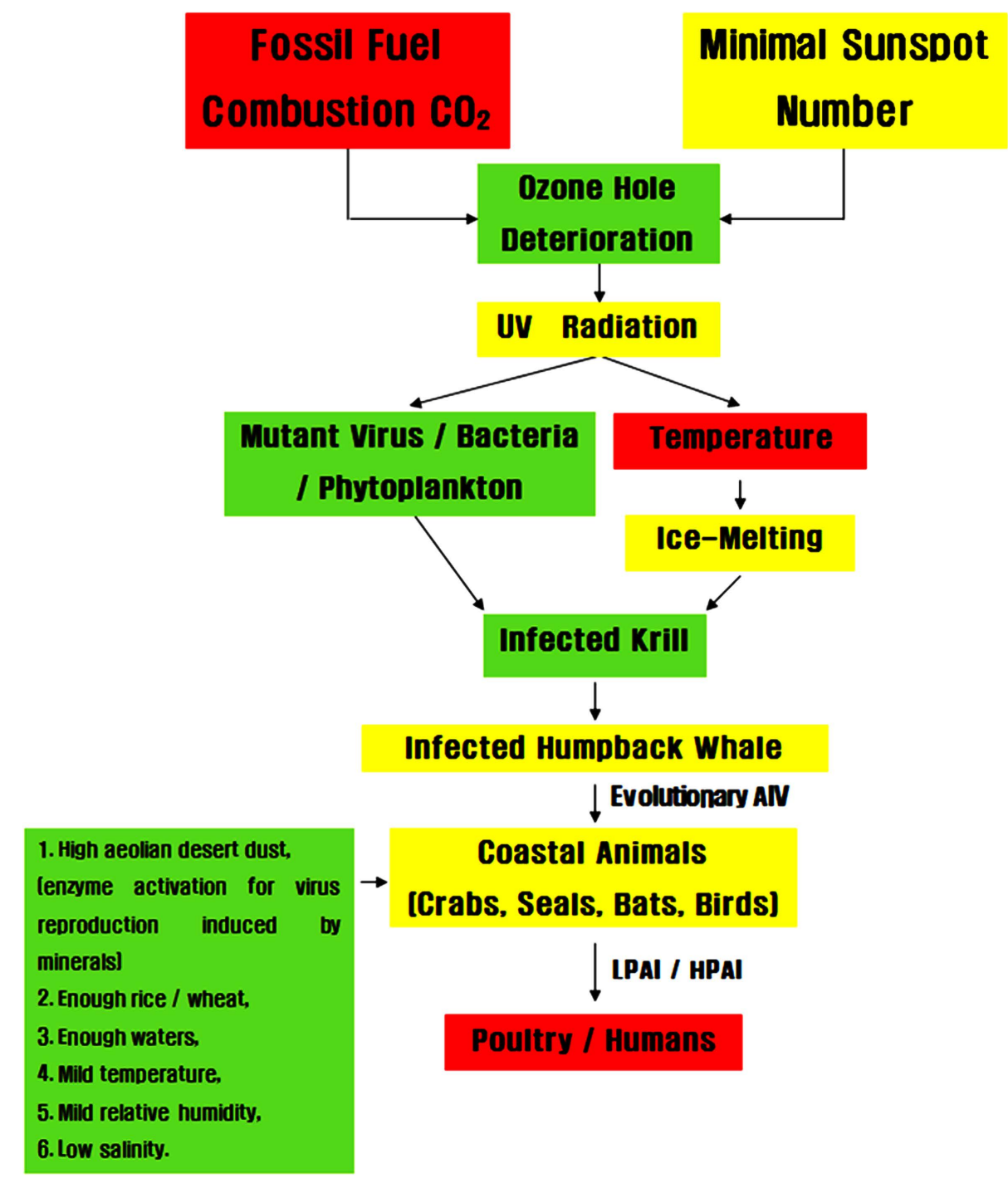

Figure 11. Sequential flow diagram of evolutionary AIV outbreak transmitted by migratory humpback whale.

\section{HUMPBACK WHALE STRANDING ALONG THE ATLANTIC COAST WITH $\mathrm{CO}_{2}$ EMISSIONS}

Humpback whales have been dying in extraordinary numbers along the Atlantic Coast since the beginning of 2016. Marine biologists have a term for it-an "unusual mortality event"-but they have no firm idea why it is happening. Forty-one whales have died in the past 15 months along the Atlantic Coast from North Carolina to Maine. Officials from the National Oceanic and Atmospheric Administration Fisheries said that they had not identified the underlying reason for the mass death, but that 10 of the whales are known to have been killed by collisions with ships. The last major mass casualty event for marine mammals in this part of the world took place from 2013 to 2015, when a resurgence of the morbillivirus killed thousands of bottlenose dolphins on the Atlantic Coast. Among humpback whales, there was an unusual mortality event in 2006, following others in 2005, which involved other large whales, and 2003, which was primarily humpback whales. In each investigation, the cause was undetermined, officials said [25]. Interestingly enough, during the minimal sunspot number $(<50)$ in 2003, 2005, 2006, 2013, 2014, 2015, and 2016, there was strong UV radiation that was enough to mutate the aquatic virus in infected krill and infected humpback whales (Figure 11) ultimately causing stranding along the Atlantic Coast. 
A dead humpback whale was observed in California (Figure 12(a)) while a dead fin whale was found on Massachusetts beach (Figure 12(b)). Such dead whales might have already been infected by the aquatic virus mutant in Poles. There were 14 humpback whales killed in the Georges Bank from the coast of Maine and Massachusetts in 1987 while 12 humpback whales have died in the same area in 2003 [9]. It was suspected that saxitoxin from deadly algae accumulated in mackerel fed on by humpback whale [26]. However, it appears that the strong UV radiation during the minimal sunspot numbers in 1987 and 2003 (Figure 8) might induce the worst evolutionary mutant viruses in the Arctic. The humpback whales feeding on krill, infected by the worst evolutionary mutant viruses in the Arctic, might have routinely migrated from the Arctic to the Gulf of Maine during summer. The humpback whales could be too exhausted to travel further due to a lack of immunity and are then stranded in Georges Bay.

The sperm whale is the largest of the toothed whales. Males can grow up to 18 meters long and females about 11 meters. They inhabit waters worldwide from the equator to the edges of the Polar pack ice. The sperm whale can dive to depths between 1000 to 2000 meters for up to two hours.

In January in 2003 Hong Kong had a sperm whale stranding. On July 21, 2003, a live young male sperm whale was discovered stranded at Tai Wan in Hong Kong in China [30]. Four sperm whales were stranded ashore on the 16th of March 2012 in Jiangsu Province. After more 24 hours of rescue attempts the four whales died. During their journey to low-latitude grounds, they might became exhausted

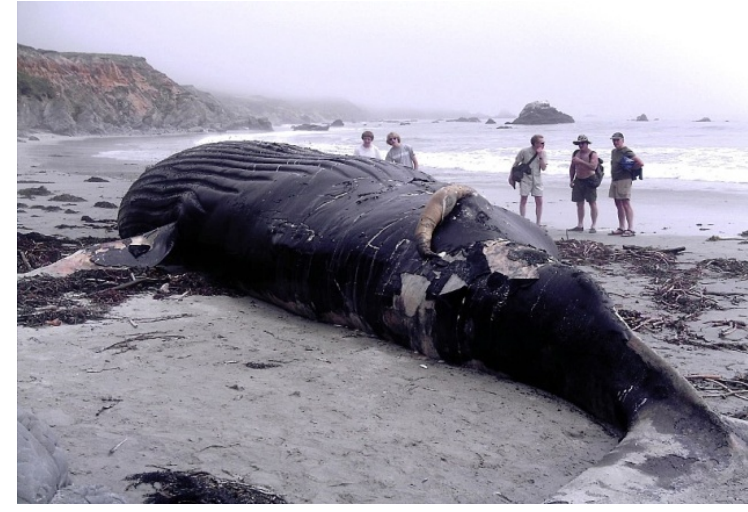

(a)

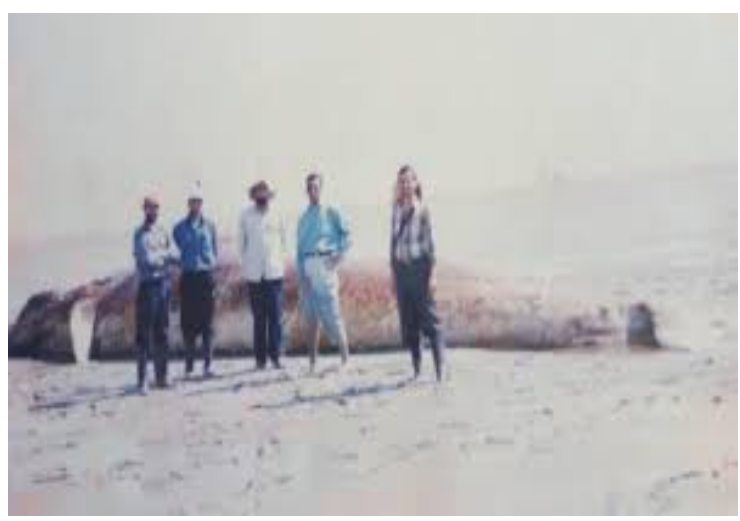

(c)

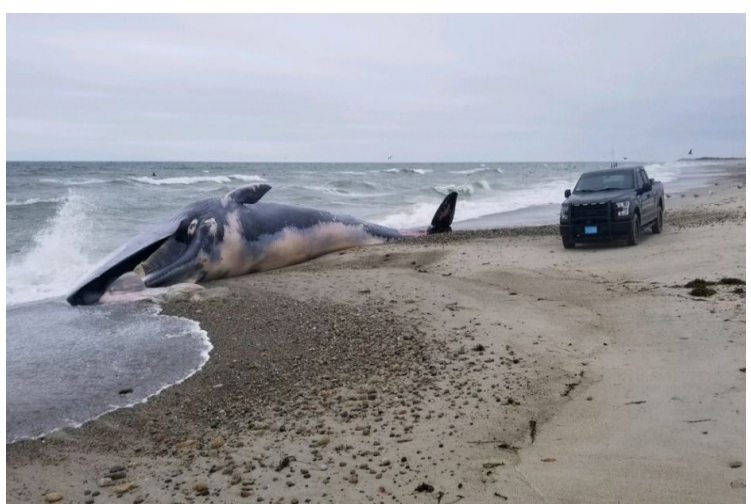

(b)

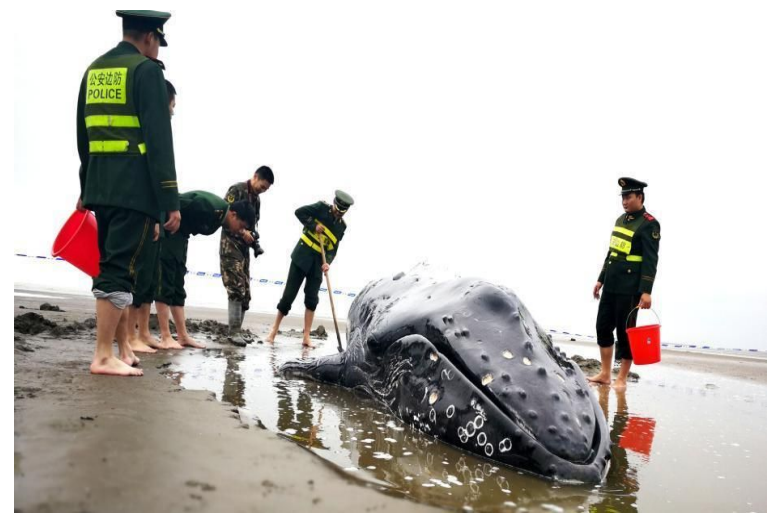

(d)

Figure 12. (a) A dead humpback washed up near Big Sur, California [7]; (b) A large, dead fin whale washed ashore by Chris Ciaccia, Fox News [27]; (c) Juvenile humpback whale stranded on Bahrekan coast, Iran, western Persian Gulf, on 12 August 1996, its death due to possible infection by the aquatic virus in Antarctica in 1996 [28]; (d) The humpback whale calf found stranded on the shore near Qidong city, Jiangsu Province of China in 2017 [29]. 
and die. Such dead bodies might be fed on by coastal animals to transmit their viruses to wild birds, bats and poultry for evolutionary AIV. Since whales are marine mammals while penguins are birds, there could be different evolutionary AIV in marine mammals (H13N2, H13N9) [2]. The direction of interspecies transmission in such a marine mammal could be from marine mammals to aquatic birds since the whales in Poles could be infected by aqueous virus and krill without passing through the host of penguins as hosts. The stranded dead whales should be burned as soon as possible to prevent further deadly viral interspecies transmission by the coastal animals (bird, bat, dolphin, crab, seal, whale) around the region. It seems that the infected humpback whales died because of the aquatic virus mutant during the $\mathrm{CO}_{2}$ emissions increase and the minimal sunspot number period and strong UV radiation. It is therefore expected that serious numbers of whales will be stranded at the Gulf of Maine (Figure 13), States of North Carolina, New York, and Virginia (Table 3) during the $\mathrm{CO}_{2}$ emissions increase and the minimal sunspot number (Figure 16) from November 2018 till April 2019.

Table 3 shows that there was a large number of humpback whale stranding along the Atlantic Coast from 2016-2018 in Delaware (5), Massachusetts (14), Maine (4), North Carolina (11), New Jersey (7), New York (17), Rhode Island (5), Virginia (14), where are major States of carbon dioxide emissions along the Atlantic Coast, as shown in Figure 14.

Figure 15 showed the relation of humpback whale stranding $(y)$ greater than 4 with carbon dioxide emissions in millions of metric tons $(x)$, expressed as $\mathrm{y}=0.0652 x+4.5847\left(\mathrm{R}^{2}=0.6128, \mathrm{p}\right.$ value $\left.=0.0074\right)$ during the years of 2016 to 2018. The number of humpback whale stranding on the Atlantic Coast was

Table 3. Humpback whale stranding along the Atlantic Coast during the years of 1992 to 2018.

\begin{tabular}{|c|c|c|c|c|}
\hline \multirow{2}{*}{$\begin{array}{c}\text { Atlantic } \\
\text { Ocean State }\end{array}$} & \multirow{2}{*}{$\begin{array}{l}{ }^{1)} \text { Annual } \mathrm{CO}_{2} \text { Emissions } \\
\text { (Millions of Metric Tons) }\end{array}$} & \multicolumn{2}{|c|}{ Humpback Whale } & \multirow[b]{2}{*}{${ }^{4)}$ AIV Outbreak } \\
\hline & & $\begin{array}{l}{ }^{2)} \text { Stranding } \\
(1992-2016)\end{array}$ & $\begin{array}{l}{ }^{3)} \text { Stranding } \\
(2016-2018)\end{array}$ & \\
\hline Delaware & 13 & 19 & 5 & 7 \\
\hline Florida & 227 & 87 & 2 & 19 \\
\hline Georgia & 139 & 14 & 1 & 60 \\
\hline Massachusetts & 64 & 202 & 14 & 7 \\
\hline Maryland & 62 & 27 & 2 & 15 \\
\hline Maine & 17 & 130 & 4 & 5 \\
\hline North Carolina & 126 & 117 & 11 & 47 \\
\hline New Hampshire & 15 & 6 & 1 & 4 \\
\hline New Jersey & 114 & 81 & 7 & 11 \\
\hline New York & 170 & 89 & 17 & 38 \\
\hline Rhode Island & 11 & 46 & 5 & - \\
\hline South Carolina & 74 & 17 & 1 & 18 \\
\hline Virginia & 103 & 72 & 14 & 60 \\
\hline
\end{tabular}

Note: ${ }^{1)}\left[32\right.$ ]. ${ }^{2)}$ [33] Humpback whales (371) were the most common large whale reported, followed by minke whales (276) from the years of 1992-2016. ${ }^{3)}$ [34] Humpback whale stranding by State from the years of 2016 to $2018 .{ }^{4)}$ [35]. 


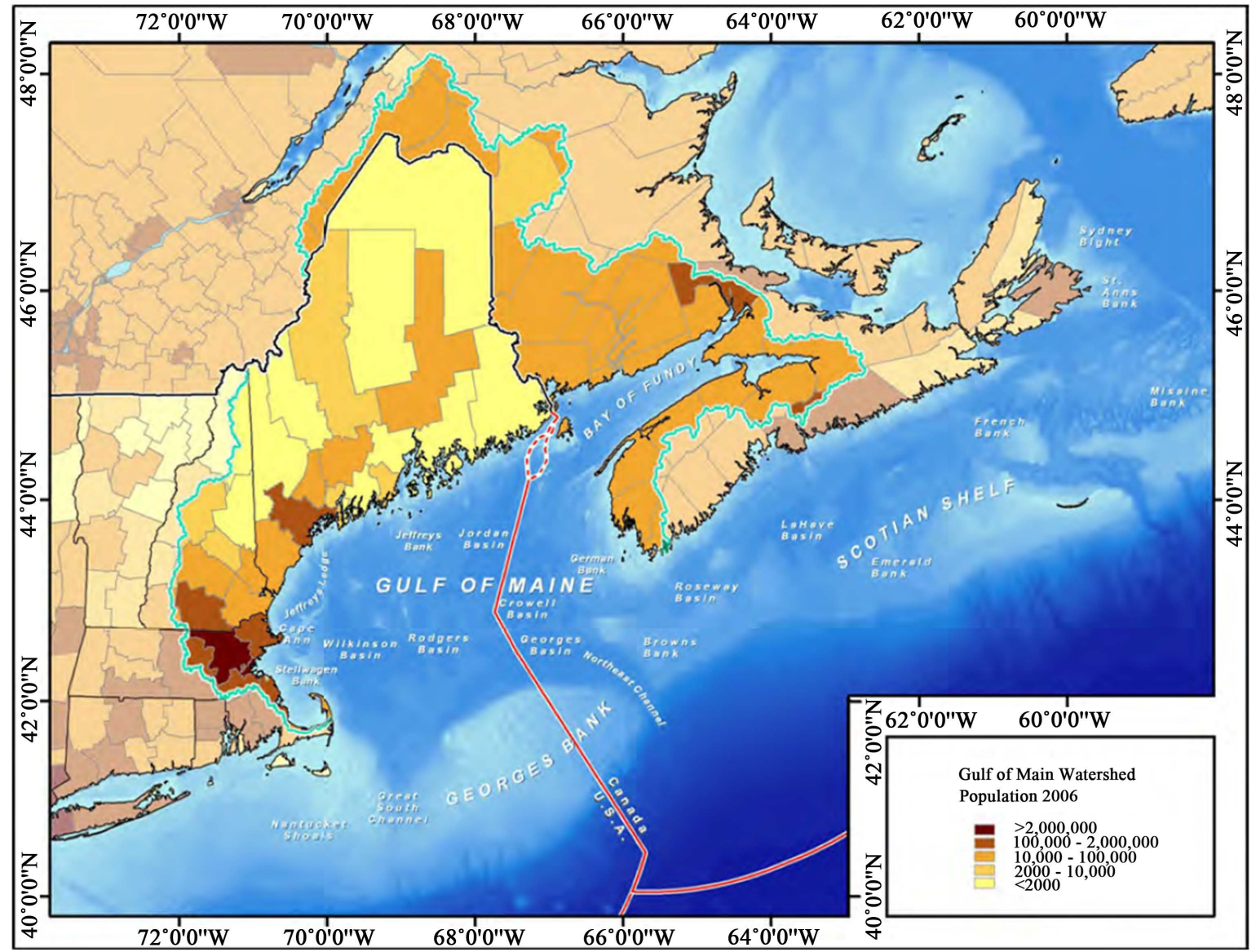

Figure 13. Population by country of the Gulf of Maine watershed [31].

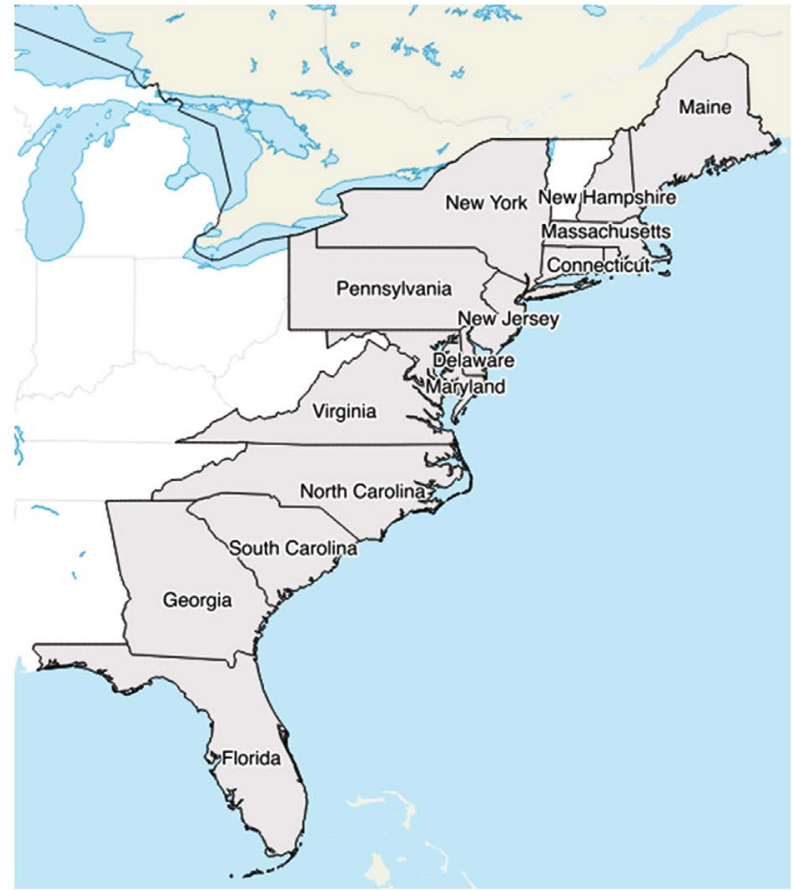

Figure 14. States along the Atlantic coast of the USA [36]. 


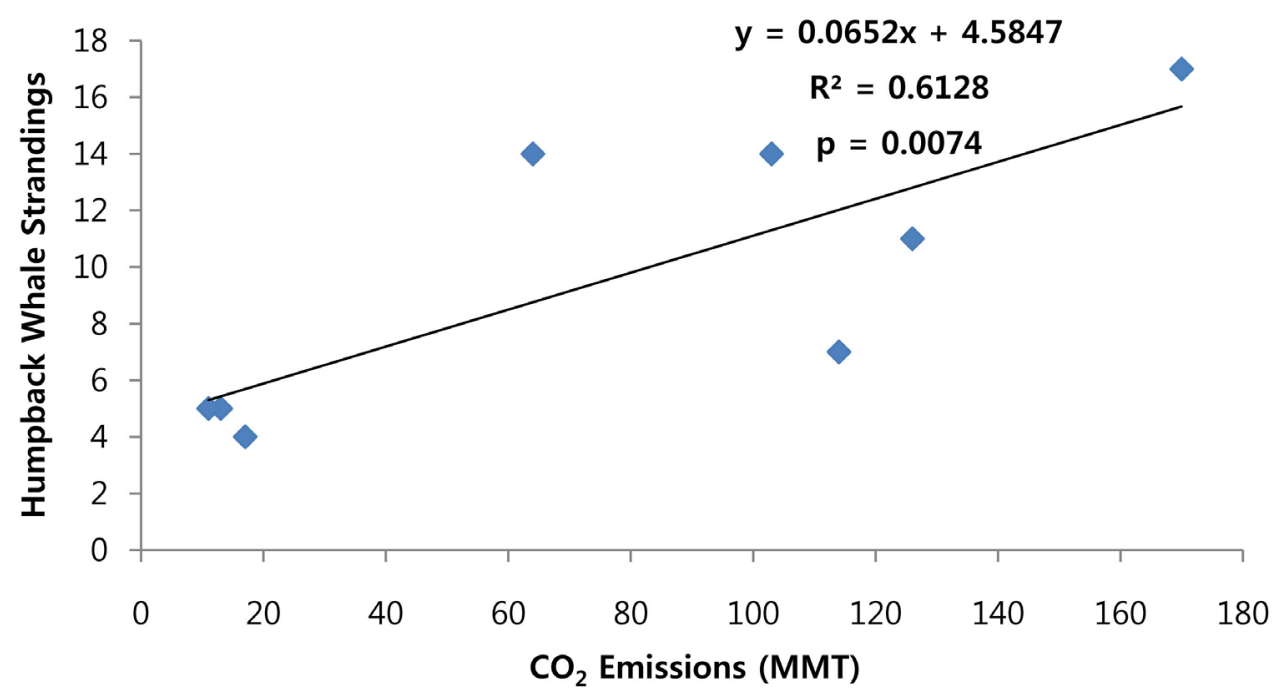

Figure 15. Relation of humpback whale stranding with carbon dioxide emissions [37] along the Atlantic Coast of the USA.

thus proportional to the annual $\mathrm{CO}_{2}$ emissions of States along the Atlantic Ocean. It could be proposed that the humpback whale unusual mortality event might be caused by carbon dioxide emissions increase. Furthermore, there were the minimal sunspot numbers in the years of 2016-2018, as shown in Figure 16.

It is proposed that $\mathrm{CO}_{2}$ emissions increase (Figure 15 and Table 3) and minimal sunspot number (Figure 16) induce the ozone hole deterioration causing the strong UV radiation. The resultant mutant virus causes the evolutionary AIV in the humpback whales feeding on the infected virus and krill in the Poles. Infected humpback whales might migrate to the Atlantic Coast with serious stranding at Massachusetts (14), North Carolina (11), New Jersey (7), Maine (4), New York (17), Virginia (14) with carbon dioxide emissions (Table 3) during minimal sunspot numbers in 2016, 2017, and 2018 (Figure 16). Since nuclear power plant do not generate $\mathrm{CO}_{2}$ emissions, the conventional $\mathrm{CO}_{2}$ emissions fossil fuel combustion plants should be replaced, so as to not to produce $\mathrm{CO}_{2}$ emissions for electricity. Humpback whales coming to the Gulf of Maine (Figure 13) may be saved so long as $\mathrm{CO}_{2}$ emissions are not increased, especially during the minimal sunspot number.

Asian H5N1 HPAI epizootic has begun in Guangdong in China in 1996. Swayne [38] concluded that it is less clear as to how H5N1 spread to eastern Asia, Middle East and Africa. In the present study, it appears that transmission by humpback whales (Figure 9(a)) may reinforce the spreading by migratory birds (Figure 1). The humpback whales 14 distinct population segments identification map by NOAA Fisheries (Figure 5) backs up the spread of AIV to Asia (S. Korea 2003-4, Japan 2004, Vietnam 2004-6, Thailand 2004-6, Cambodia 2004-6, Laos 2004-6, Taiwan 2003\&5, Indonesia 2003-6, Malaysia 2004), Middle East (Late-2005: Turkey, Romania, Kuwait, Croatia, Ukraine, Cyprus, Egypt, Gaza Strip, Israel, Jordan, Iraq, Iran, Afghanistan, Pakistan) by the segment 14, and Africa (2006: Nigeria, Cameroon, Niger, Burkina Faso, Cote d'Ivoire, Sudan) by the humpback whale segments 2,8 , and 9 (Figure 5). It is proposed that the cumulative spread by both the migratory birds via airway and the humpback whales via seaway (Table 2 and Figure 9(a)) may be the sources of AIV for poultry and humans. Therefore, the dead bodies of migratory birds and stranded or floating whales should be burned so as not to spread infection further via aerosol or coastal animals. The West Indies is one of 14 humpback whale habitats (Figure 5). Humpback whales feeding on shrimp and fish in Greenland and Iceland during summer migrate to New Foundland, Maine and Massachusetts (Figure 13) during winter. Table 3 shows humpback whale stranding in the Atlantic Coast States from 1992 to 2018. All the data from 1992-2016 was plotted in Figure 17 to see the relation of $\mathrm{CO}_{2}$ emission $(x)$ with number of stranding humpback whales $(y)$ as $y=0.1461 x+57.013\left(\mathrm{R}^{2}=\right.$ 0.0297 ) with $\mathrm{p}$ value of 0.5392 . Since Maine and Massachusetts are major stopovers on the way to the West 
ISES Solar Cycle sunspot Number Progression

Observed data through Sep 2018

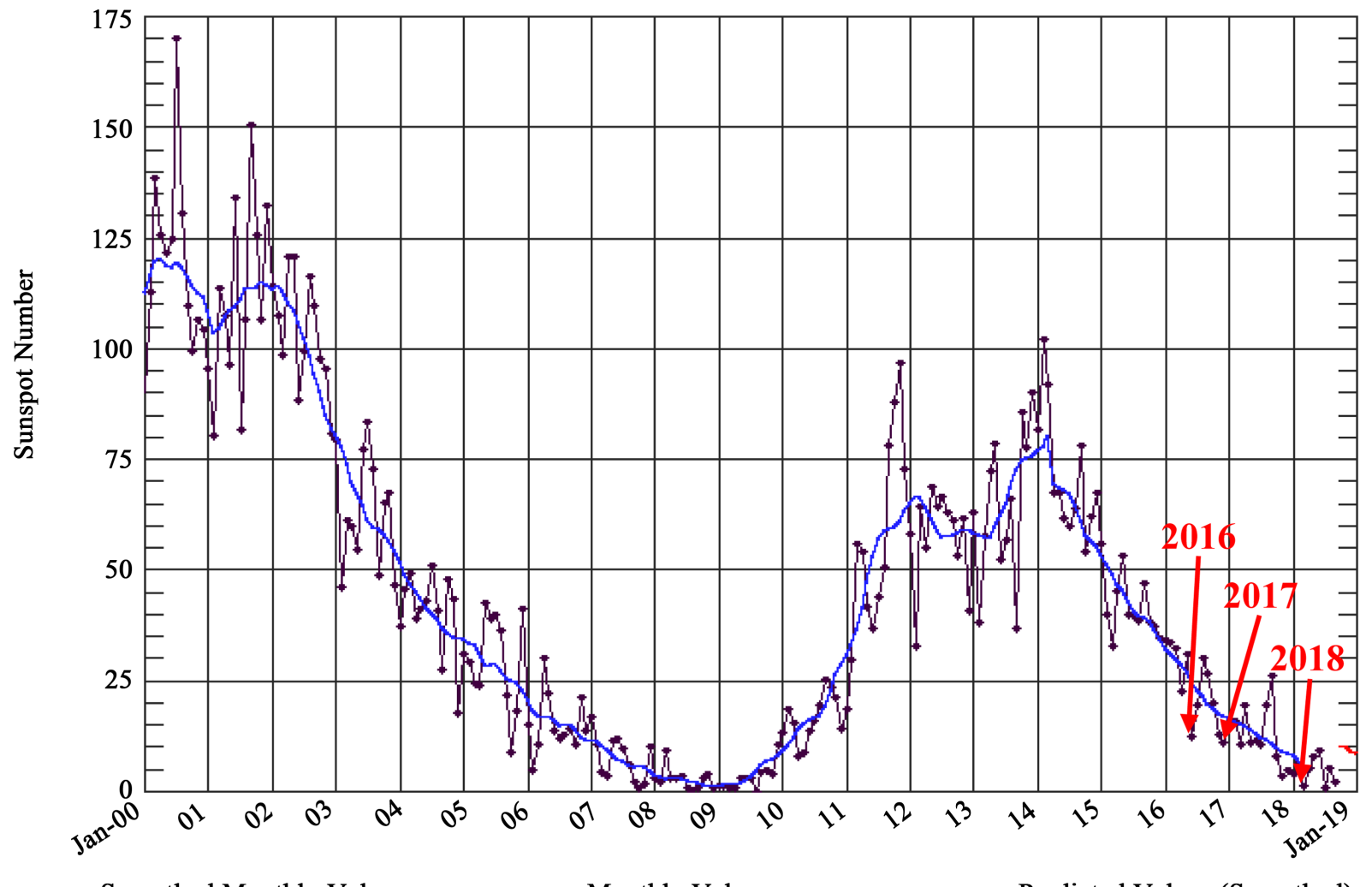

Smoothed Monthly Values

Monthly Values

Predicted Values (Smoothed)

Updated 2018 Oct 8

NOAA/SWPC Boulder, CO USA

Figure 16. Minimal sunspot number during 2016-2018 [19].

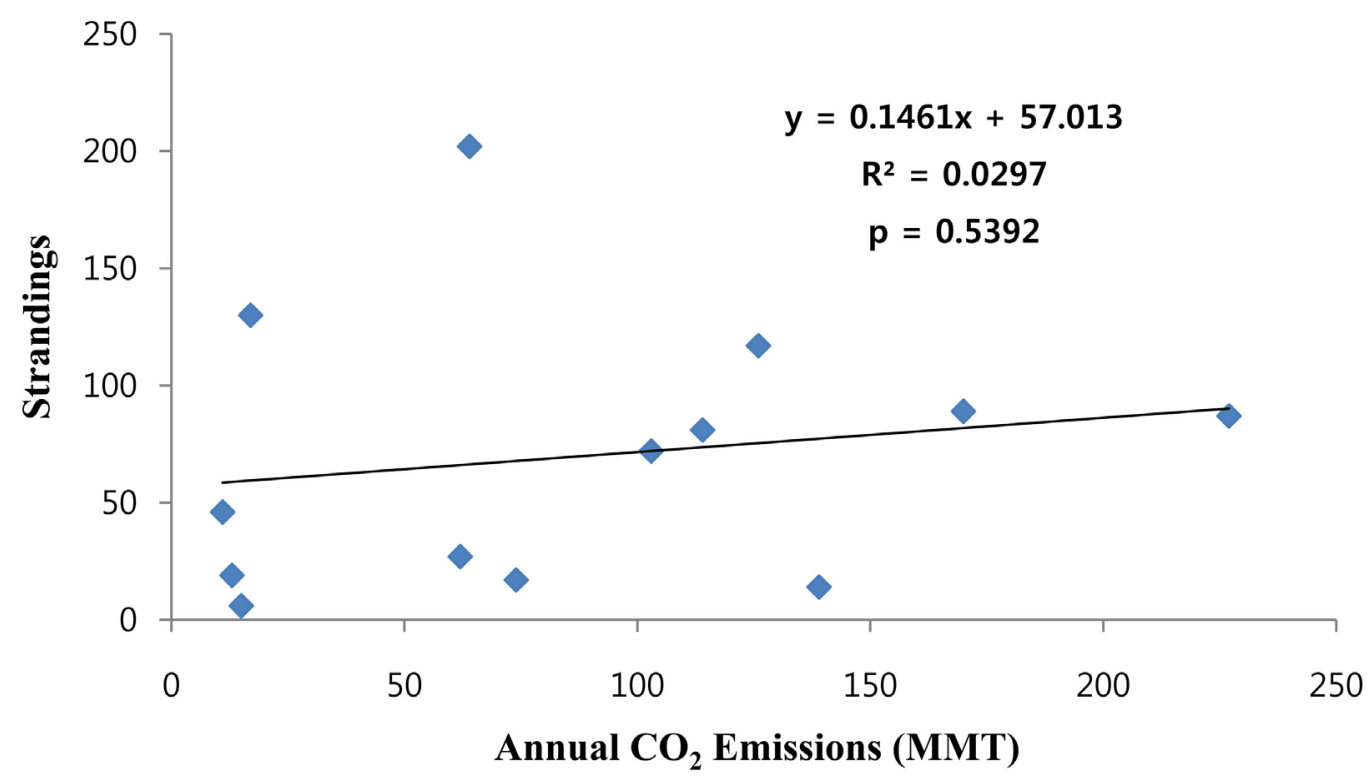

Figure 17. Humpback whale stranding with respect to annual $\mathrm{CO}_{2}$ emissions along the Atlantic Coast during 1992-2016. 
Indies (Figure 5), their data of stranded humpback whales may not realistically represent their dependency upon the low $\mathrm{CO}_{2}$ emissions in Maine and Massachusetts (Table 3). These two points were thus deleted to get Figure 18 as $y=0.3515 x+18.595\left(\mathrm{R}^{2}=0.4069\right)$ with $\mathrm{p}$ value of 0.0190 . As for the data during 2016-2018, Figure 19 was plotted as $y=0.0652 x+4.5847\left(\mathrm{R}^{2}=0.6128\right)$ with stranding number greater than 4 whose $\mathrm{p}$ value was 0.0074. Based upon the results shown in Figure 18 and Figure 19, it could be proposed that the humpback whales, the presumably infected by the mutant virus in the Arctic and migrating along the Atlantic Coast toward the West Indies, might be annually stranded by the $\mathrm{CO}_{2}$ emissions from the States along the Atlantic Coast during the minimal sunspot number period.

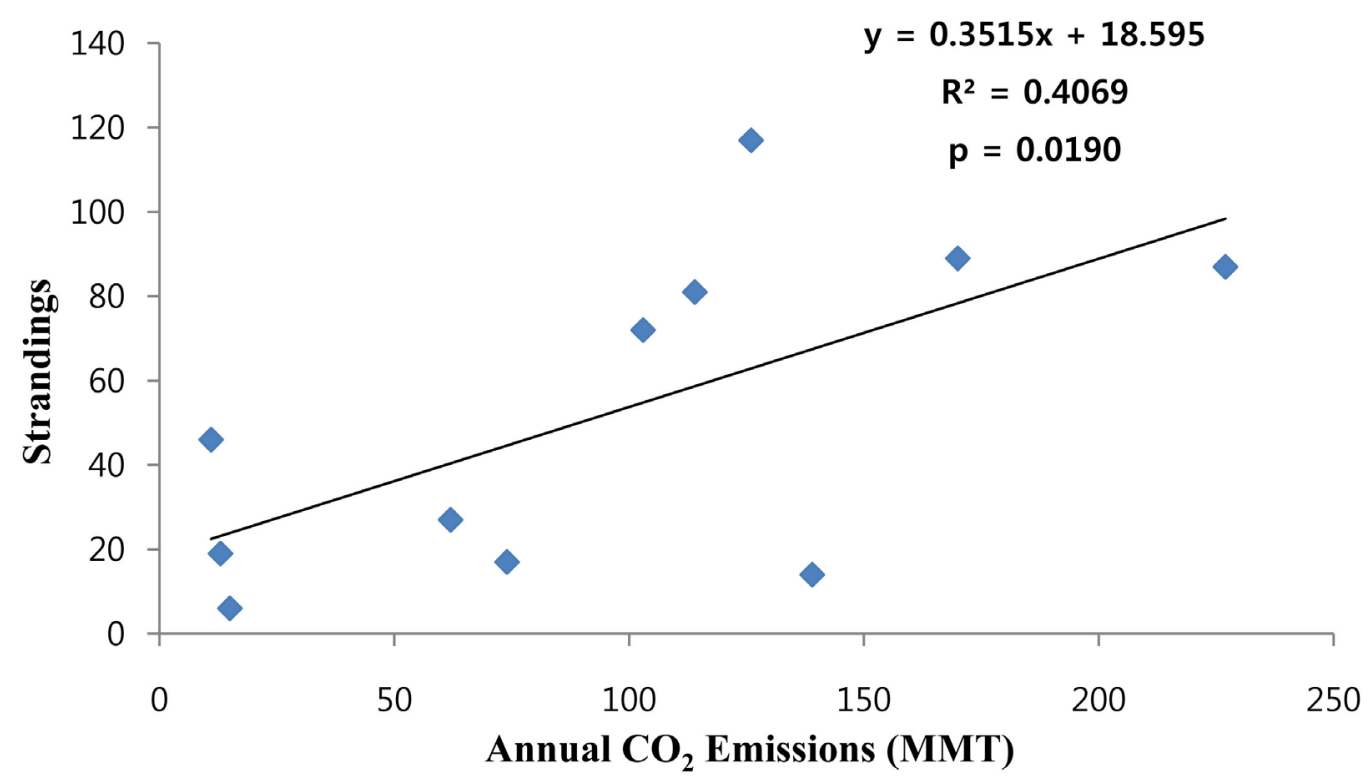

Figure 18. Humpback whale stranding with respect to annual $\mathrm{CO}_{2}$ emissions along the Atlantic Coast except Maine and Massachusetts with low $\mathrm{CO}_{2}$ emissions during 1992-2016.

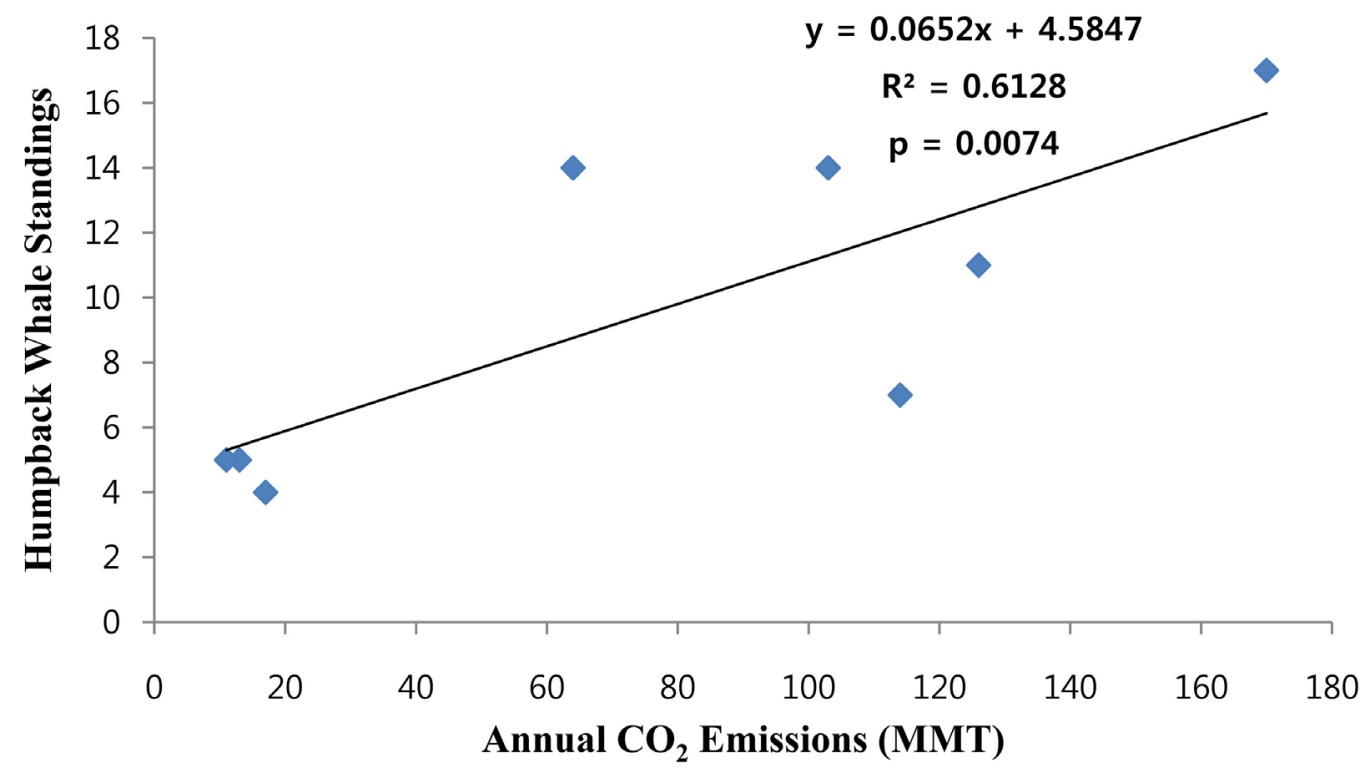

Figure 19. Humpback whale stranding greater than 4 with respect to annual $\mathrm{CO}_{2}$ emissions along the Atlantic Coast during 2016-2018. 
The humpback whale infected by the mutant virus in the Arctic during the $\mathrm{CO}_{2}$ emissions increase and the minimal sunspot number, might migrate to New Foundland, Maine, and Massachusetts. Their final destination during summer is the West Indies while humpback whales have to pass the Atlantic Coast States with extensive $\mathrm{CO}_{2}$ emissions, which might result in yearly stranding of humpback whales along the Atlantic Coast. There was a significant relation (Figure 19, $\mathrm{p}=0.0074$ ) between the annual $\mathrm{CO}_{2}$ emissions and humpback whales stranding along the Atlantic Coast from 2016 to 2018. It was proposed that humpback whales in the Gulf of Maine have been already infected by the mutant virus in the Arctic to be stepwise stranded along the Atlantic Coast during the path to the winter habitat of the West Indies. Such humpback whales were affected by $\mathrm{CO}_{2}$ emissions, available from major $\mathrm{CO}_{2}$ producing Atlantic Coast States (Table 3), to be stranded and initially infected in the Arctic by evolutionary AIV which results in their inevitable slow death. To save humpback whales from the Atlantic Coast, the reduction of $\mathrm{CO}_{2}$ emissions is suggested by replacement of fossil fuels combustions plants with nuclear power plants for electricity along the Atlantic Coast of the USA.

Figure 20 showed that whale stranding $(x)$ along the Atlantic Coast from 2016-2018 were correlated with AIV outbreak in such States in 2010 [35] $(y)$ as $y=0.1387 x+6.8184$ with p value of 0.0691 . Kim [4] proposed that the year of AIV outbreak was significantly related with the year of the minimal sunspot number $\left(\mathrm{R}^{2}=0.9967\right)$. Therefore, the present suggestion of whale stranding induced by both of the $\mathrm{CO}_{2}$ emissions (Figure 18 and Figure 19) and the minimal sunspot number (Figure 11 and Figure 20) may be reasonable.

\section{CONCLUSIONS}

Humpbacks are migratory, spending summers in cooler, high-latitude waters and mating and calving in tropical and subtropical waters in 14 identified humpback whale district population segments. It may be possible that the coastal areas are infected with LPAIV during the release of infected humpback whale feces of 1.5 ton per day from the Polar waters to tropical or subtropical waters. Therefore, humpback whales can be an effective reservoir of AIV spreading evolutionary AIV from the Poles to marine mammals and coastal wild aquatic birds. The present study suggested the similarity of AIV transmission in the seasonal migration between commonly known migratory birds and presently revealed humpback whales from high-latitude feeding grounds (Poles) to low-latitude breeding grounds (Continents) so that AIV was also

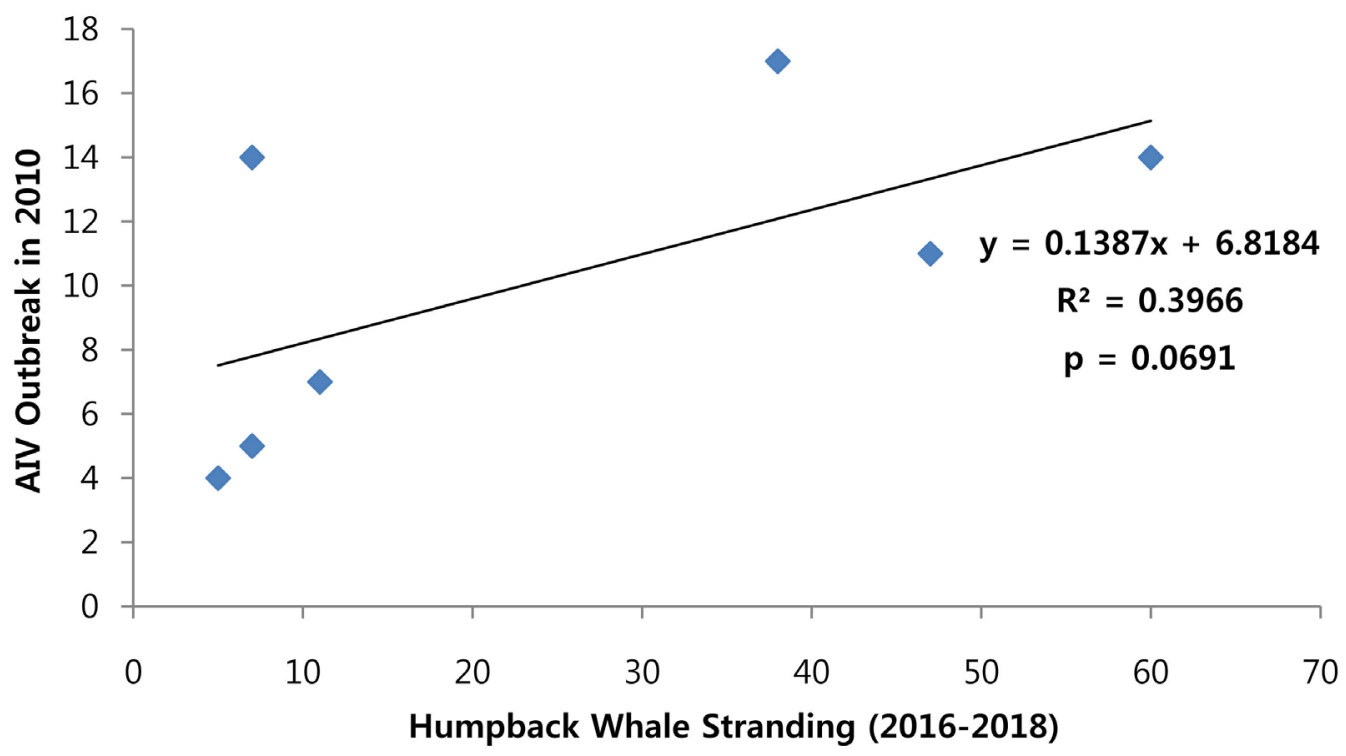

Figure 20. Relation of humpback whale stranding (2016-2018) along the Atlantic Ocean with AIV outbreak in 2010 [35] in the USA. 
transmitted by humpback whales. The seaways of humpback whale or whales including dolphins and seals should be considered when planning the prevention of AIV outbreaks in addition to the flyways of migratory birds. Since nuclear power plants do not produce $\mathrm{CO}_{2}$ emissions, the conventional $\mathrm{CO}_{2}$ emissions fossil fuel combustion plants should be replaced so as to not to produce $\mathrm{CO}_{2}$ emissions for electricity. Strong UV-B exposure, with both $\mathrm{CO}_{2}$ emission increase and minimum sunspot number, might cause evolutionary mutations of aquatic virus, bacteria, phytoplankton, zooplankton, krill, small fish, squid, penguins, migratory birds, and humpback whales in the Antarctic and the Arctic. LPAI or HPAI were expressed in the Continents under appropriate environmental factors. Since penguins are birds while humpback whales are marine mammals, the humpback whales infected by the mutant virus might cause interspecies transmission in a new host with evolutionary changes. Marine mammals with AIV, such as harbor seals, elephant seals, and pilot whales, could be directly infected by humpback whale feces and indirectly infected by wild aquatic birds. AIV has a reservoir of penguins, whose mutant virus is transmitted by migratory birds to Continents. Humpback whales are a reservoir of mammalian animal, whose mutant virus of evolutionary AIV is transmitted in humpback whales to Continents. The migration pattern is seasonally similar between migratory birds and humpback whales except: 1) different species of bird versus whale, 2) different landing area versus coast, 3) similar infection means of bird feces versus humpback whale feces. The sum of humpback, pilot, and minke whales in the Poles weighs 6.4 billion kg. If assuming one $\mathrm{kg}$ per migratory bird for billions of migratory birds in the world, the contribution of AIV transmission by whales is several times larger than that by migratory birds. Therefore, the routes of humpback whale including dolphins and seals should be considered when attempting prevention of AIV outbreaks in addition to the flyways of migratory birds. Humpback whales have been dying in extraordinary numbers along the Atlantic Coast in unusual mortality event. Humpback whale stranding $(y)$ along the Atlantic Coast of the USA from 1992-2018, was related with $\mathrm{CO}_{2}$ emissions $(x)$ to have $y=0.3515 x+18.595\left(\mathrm{R}^{2}=0.4069\right.$, $\mathrm{p}$ value $=$ $0.0190)$ from $1992-2016$ while $y=0.0652 x+4.5847\left(\mathrm{R}^{2}=0.6128, \mathrm{p}\right.$ value $\left.=0.0074\right)$ from 2016-2018. AIV outbreaks along the Atlantic Coast (y) were related with humpback whale stranding (2016-2018) $(x)$ as $y=$ $0.1387 x+6.8184\left(R^{2}=0.3966, p\right.$ value $\left.=0.0691\right)$. Since AIV outbreak was linearly $\left(\mathrm{R}^{2}=0.9967\right)$ related with the minimum sunspot number, it was proposed that unusual mortality events of humpback whale stranding along the Atlantic Coast of the USA might be caused by the aquatic virus mutant during the $\mathrm{CO}_{2}$ emissions and the minimal sunspot number and strong UV radiation on the path to the winter habitat of the West Indies. The stranded dead whales should be burned as soon as possible to prevent further deadly viral interspecies transmission by the coastal animals (bird, bat, dolphin, crab, seal, whale) around the region. Since $\mathrm{CO}_{2}$ emissions were abruptly increased in 2017 and the sunspot number reaches its minimal point at the end of 2018, serious numbers of whales are expected to be stranded in the Gulf of Maine, States of North Carolina, New York, and Virginia during November 2018 till April 2019. To save humpback whales from the unusual mortality event along the Atlantic Coast, the reduction of $\mathrm{CO}_{2}$ emissions is suggested by replacement of fossil fuels combustion plants along the Atlantic Coast of the USA with nuc-

lear power plants for electricity.

\section{ACKNOWLEDGEMENTS}

The author expresses sincere gratitude to G-Land and the University of Suwon of South Korea for their financial support. Editing work undertaken by Professor Jonathan Wright is also greatly appreciated.

\section{CONFLICTS OF INTEREST}

The authors declare no conflicts of interest regarding the publication of this paper.

\section{REFERENCES}

1. List of Coast Animals. http://www.skyenimals.com/browse_habitat.cgi?habitat=coasts

2. Yoon, S.W., Webby, R.J. and Webster, R.G. (2014) Evolution and Ecology of Influenza a Viruses. Current Top- 
ics in Microbiology and Immunology, 385, 359-375. https://doi.org/10.1007/82_2014_396

3. http://jnana.tistory.com/822

4. Kim, T.J. (2018) Prevention of Avian Influenza Virus by Ultraviolet Radiation and Prediction of Outbreak by Satellite Parameters. Journal of Biomedical Science and Engineering, 11, 182-206.

https://doi.org/10.4236/jbise.2018.117015

5. Osterhaus, A.D., Rimmelzwaan, G.F., Martina, B.E., Bestebroer, T.M. and Fouchier, R.A. (2000) Influenza B Virus in Seals. Science, 288, 1051-1053. https://doi.org/10.1126/science.288.5468.1051

6. AI Outbreaks: OIE, FAO, and Government Sources. Flyways: Wetlands International (2005).

7. Wikipedia-Humpback Whale.

8. https://www.whales.org.au/discover/hump/humpm.html

9. National Oceanic and Atmospheric Administration (NOAA) Fisheries, Humpback Whale (Megaptera novaeangliae) (2015) http://www.nmfs.noaa.gov/pr

10. http://www.whale-watching-alaska.com/whale/humpbackwhalesalaska.html

11. Gill, P. and Gibson, L. (1997) Whales, Dolphins and Porpoises. Reader's Digest Association, Inc., New York \& Montreal, 160.

12. https://www.prideofmaui.com/trips/whale/

13. Aquilina, A., Homoky, W.B., Hawkes, J.A., Lyons, T.W. and Mills, R.A. (2014) Hydrothermal Sediments Are a Source of Water Column Fe and Mn in the Bransfield Strait. Antarctica. Geochimica et Cosmochimica Acta, 137, 64-80. https://doi.org/10.1016/j.gca.2014.04.003

14. Venables, H. and Moore, C.M. (2010) Phytoplankton and Light Limitation in the Southern Ocean: Learning from High-Nutrient, High-Chlorophyll Areas. Journal of Geophysical Research, 115, C02015. https://doi.org/10.1029/2009JC005361

15. Giardino, C., Pepe, M., Brivio, P.A., Ghezzi, P. and Zilioli, E. (2001) Detecting Chlorophyll, Secchi Disk Depth and Surface Temperature in a Sub-Alpine Lake Using Landsat Imagery. Science of the Total Environment, 267, 19-29. https://doi.org/10.1016/S0048-9697(00)00692-6

16. The IUCN Red List of Threatened Species-Megaptera novaeangliae. http://www.iucnredlist.org/details/13006/0

17. Wikipedia-Pilot Whale.

18. Tracey, J. (2004) Targeting Surveillance for Avian Influenza in Wild Birds: A Pilot Investigation in New South Wales. Australian Government.

19. Hathaway, D.H. (2015) The Solar Cycle. Living Reviews in Solar Physics, 12, 4. https://doi.org/10.1007/lrsp-2015-4

20. Hathaway, D.H. (2010) The Solar Cycle. Living Reviews in Solar Physics, 7, 1. https://doi.org/10.12942/lrsp-2010-1

21. https://phys.org/news/2014-01-asian-ozone-pollution-hawaii-tied.html\#ampshare=https://phys.org/news/201401-asian-ozone-pollution-hawaii-tied.html

22. Langslow, D.R. (1976) Weights of Blackcaps on Migration. Ringing \& Migration, 1, 78-91. https://doi.org/10.1080/03078698.1976.9673706

23. EAAFP Secretariat (2014).

24. Dhingra, M.S., Artois, J., Robinson, T.P., Linard, C., Chaiban, C., Xenarios, I., Engler, R., Liechti, R., Kuznetsov, D., Xiao, X., Dobschuetz, S.V., Claes, F., Newman, S.H., Dauphin, G. and Gilbert, M. (2016) Global Mapping of Highly Pathogenic Avian Influenza H5N1 and H5Nx Clade 2.3.4.4. Viruses with Sptial Cross-Validation. eLife, 5, e19571. https://doi.org/10.7554/eLife.19571 
25. Schlossberg, T. (2017) Mass Die-Off of Whales in Atlantic Is Being Investigated. The New York Times.

26. Pearson, H. (2003) Toxic Algae Suspected in Whale Death. Red Tide's Poison May Have Killed a Dozen Humpbacks in North Atlantic. Nature.

27. Ciaccia, C. (2018) Enormous Dead Whale Washes Ashore on Massachusetts Beach. Fox News.

28. https://www.biorxiv.org/content/biorxiv/early/2017/09/06/185033.full.pdf

29. Dehua, C. (2017) Stranded Humpback Whale Dies on East China Beach Despite Two Rescue Attempts. Bringing China Closer.

30. Hong Kong Dolphin Conservation Society, Cetaceaus in Hong Kong.

31. US Census Bureau (2009) Statistics Canada.

32. List of U.S. States by Carbon Dioxide Emissions. https://en.m.wikipedia.org

33. NOAA Fisheries (1992-2016) East Coast Large Whale Strandings.

34. NOAA Fisheries (2018) 2016-2018 Humpback Whale Unusual Mortality Event along the Atlantic Coast.

35. Fuller, T.L., Saatchi, S.S., Toffelmier, E., Thomassen, H.A., Buermann, W., DeSante, D.F., Nott, M.P., Saracco, J.F., Ralph, C.J., Alexander, J.D., Pollinger, J.P. and Smith, T.B. (2010) Mapping the Risk of Avian Influenza in Wild Birds in the US. BMC Infectious Diseases, 10, 187. https://doi.org/10.1186/1471-2334-10-187

36. https://goo.gl/images/XfPvK2

37. State Energy $\mathrm{CO}_{2}$ Emissions (2016) US Environmental Protection Agency.

38. Swayne, D.E. (2006) Avian Influenza: HPAI Outbreaks and Control Methods. Dev. Biol. (Basel), 119, $219-228$. 